\title{
Domenico Scarlatti, artista fugidio: visões de seu "estilo misto" ao fim do século XVIII
}

\author{
Domenico Scarlatti, Escape Artist: Sightings of his "Mixed Style" towards \\ the End of the Eighteenth Century
}

Janet Schmalfeldt

Tradução de Gabriel Navia

\begin{abstract}
Resumo: Uma mudança permanente aos 34 anos de idade, da Itália para os serviços privados da princesa Maria Bárbara, em Portugal e posteriormente na Espanha, permitiu que Domenico Scarlatti fugisse da fama e da classificação estilística. Na ausência de uma categoria convincente para a música de Scarlatti - pós-Barroca? Pré-Clássica? Galante? Transitória? - o especialista em Scarlatti, W. Dean Sutcliffe, recorre à expressão adequada "estilo misto". Entretanto, Sutcliffe reconhece que "muito das sonatas de Scarlatti deve ser considerado à luz do estilo Clássico", e eu também. Particularmente, o tipo específico de forma bipartida que o compositor emprega na maior parte de suas 555 sonatas para teclado sobreviventes dificilmente era único no continente durante o tempo em que viveu, e esta forma continuou a aparecer mesmo muito depois de dar lugar ao que hoje chamamos de "sonata Clássica". Os "mecanismos de escape" musicais do compositor - atrasos surpreendentes de resultados esperados por meio de cadências evadidas e repetições "mais uma vez" - podem ser "avistados" em grande parte do repertório do fim do século XVIII, especialmente na música de Mozart. Todavia, nenhuma comparação da música de Scarlatti com a de seus sucessores pode diminuir sua exuberância "espanhola", sua predileção pela justaposição de ideias totalmente diferentes em um único movimento - resumindo, suas contribuições características e sem paralelo para a música para teclado.
\end{abstract}

Palavras-chave: A forma sonata Tipo 2 de Hepokoski e Darcy; Estratégias cadenciais; A técnica "mais uma vez"; Virtuosismo com sequências

Abstract: A permanent move at the age of 34, from Italy into the private services of Princess
Maria Bárbara in Portugal, later in Spain, allowed Domenico Scarlatti to escape fame and
stylistic classification. In the absence of a convincing category for Scarlatti's music - post-
Baroque? pre-Classical? galant? transitional? - the Scarlatti scholar W. Dean Sutcliffe resorts
to the apt expression "mixed style". But Sutcliffe acknowledges that "much about the
Scarlatti sonatas demands to be considered in the light of the Classical style", and so do I. In
particular, the specific type of two-part form that the composer employs in most of his 555 
extant keyboard sonatas was hardly unique on the continent during his lifetime, and that form continued to appear long after it had yielded to what we today call "the Classical sonata". The composer's musical "escape mechanisms" - surprising delays of expected outcomes by way of evaded cadences and 'one-more-time' repetitions - can be "sighted" in much repertoire towards the end of the eighteenth century, especially in the music of Mozart. Just the same, no amount of comparison of Scarlatti's music with that of later composers can diminish his "Spanish" flamboyance, his penchant for the juxtaposition of wildly different ideas within a single movement - in short, his unparalleled, signature contributions to keyboard music.

Keywords: Hepokoski/Darcy's Type 2 sonata form; Cadence strategies; The "one-moretime" technique; Virtuosity with sequences

Domenico Scarlatti: inegavelmente um dos maiores compositores de música para teclado e, ainda assim, o mais inescrutável de todos. O que sabemos com certeza sobre ele? Em primeiro lugar, sabemos que não há muito o que saber. Imagine se Couperin, ou Rameau, ou Sebastian Bach, ou Handel, todos contemporâneos muito próximos, houvessem deixado apenas três declarações verbais para que seus biógrafos quebrassem a cabeça - uma carta, uma dedicatória rebuscada a um rei e um prefácio para a única publicação autorizada pelo compositor. ${ }^{1}$ Imagine se todos os manuscritos autógrafos das obras para teclado destes compositores houvessem desaparecido, deixando indeterminada a questão de suas cronologias. Esta foi a desafortunada situação de Scarlatti. Tivesse isso ocorrido com os outros, eles também poderiam ter sofrido algo comparável à posição marginal ocupada por Scarlatti atualmente nos livros de história da música.

Adicione a esses fatos concretos os seguintes detalhes. Somente em 1991, pesquisadores da vida e obra de Scarlatti puderam concordar de forma mais ou menos definitiva sobre o ano e o mês em que o compositor emigrou da Itália, seu país natal, para assumir, em Lisboa, os cargos de Mestre da Capela Real e professor de teclado da família real portuguesa. Uma evidência rara confirmou sua chegada à corte em 29 de novembro de 1719, com 34 anos de idade; ${ }^{2}$ mas os

\footnotetext{
${ }^{1}$ A dedicatória e o prefácio de Scarlatti estão incluídos em seu Essercizi per Gravicembalo, uma coleção de trinta sonatas dedicada ao Rei João V de Portugal e publicada em Londres em 1738. A única carta de Scarlatti de próprio punho que se tem conhecimento foi enviada ao duque de Huescar (Don Fernando de Silva y Alvarez de Toledo) em 1752.
}

2 Vide Doderer (1991, p. 9-10), como citado em Sutcliffe (2003, p. 69 n. 202). 
MUSICA THEORICA Revista da Associação Brasileira de Teoria e Análise Musical 2020,

v. 5, n. 1, p. 1-52 - Journal of the Brazilian Society for Music Theory and Analysis @ TeMA 2020 - ISSN 2525-5541

detalhes sobre seu treinamento musical inicial, seus empregos durante a juventude e seus cargos em Veneza e Roma têm sido difíceis de localizar. Por exemplo, com quem ele estudou composição, além de, presumivelmente, seu incrível pai napolitano, Alessandro? ${ }^{3}$ Ele deixou a Itália para escapar do controle legal de um pai autoritário, ou talvez para renunciar ao tédio de escrever mais óperas, cantatas e música sacra? Sabe-se que, durante a década de 1720, ele fez algumas viagens a Paris e voltou várias vezes a Roma, onde se casou com sua primeira esposa. ${ }^{4}$ Mas pouco depois de 1728, quando a Princesa portuguesa, Maria Bárbara, se casou com o Príncipe Fernando, herdeiro da coroa espanhola, Scarlatti seguiu a futura rainha consorte, primeiro a Sevilha e depois a Madri, onde permaneceu como seu professor protegido, às escondidas, e músico da corte, escrevendo sonatas para ela até a sua morte em 1757.

Isso levanta outra questão ainda não respondida. A quem, e a que país, pertence Scarlatti? Seria à sua única aluna de teclado conhecida, a portuguesa Maria Bárbara? À Itália, sua terra natal? À Espanha, onde morou por quase metade de sua vida? ${ }^{5}$ Scarlattianos da Itália têm reivindicado sua música avidamente - "a 'personificação' da luz mediterrânea, lógica, destacamento, alegria e elegância". ${ }^{6}$ Até algumas décadas atrás, historiadores da música

\footnotetext{
3 Francesco Gasparini (1661-1727) é tido como provável professor de Scarlatti em Roma ou Veneza, onde ele também pode ter sido apresentado a Vivaldi e, certamente, conheceu Handel; vide Boyd (1987, p. 15, 100 e 163). Gjerdingen (2007) dá por certo que Gasparini foi professor de Scarlatti, afirmando, ao mesmo tempo, que "boa parte do treinamento desse músico precoce já estava concluído no final do século XVII" (p. 95) e que ele teve "experiências variadas em muitos dos grandes centros da música galante" (p. 182). Segundo Sanguinetti (2012, p. 59 e 63), Scarlatti foi um dos muitos alunos (incluindo Gasparini) de Bernardo Pasquini (1637-1710), e estudou também com Gaetano Greco (ca. 1657-1728). Estas associações merecem consideração; Sanguinetti considera Pasquini e os irmãos Greco, Rocco e Gaetano, como fundadores da tradição napolitana do partimento (p. 59), com o pai de Domenico, Alessandro, como colaborador e professor de partimento e regole (regras). Sanguinetti observa que a principal fonte da coleção de regole e lezioni de Alessandro Scarlatti leva a data de 1715 (p. 60).

${ }^{4}$ Para um resumo e discussão de fontes documentárias das atividades de Scarlatti entre os anos de 1719 e 1729, vide d'Alvarenga (2008, p. 17-68).

${ }^{5}$ Para Pestelli, "existem dois Domenico Scarlattis. Há o italiano e o espanhol [. . . ] há o bom músico que fala uma língua comum sem se preocupar em ser original e o gênio que inventa combinações sonoras nunca antes ouvidas, um homem totalmente absorvido por uma busca constante que parece excluir a ideia aceita de público [. . .] o típico problema historiográfico da origem de um estilo está fadado a permanecer sem solução no caso de Domenico Scarlatti" (1985, p. 79).
}

6 Sutcliffe (2003, p. 5); vide também a lista que Sutcliffe denomina "Instant Latinate Essentials Generator" (p. 57-58). 
espanhola pareciam desinteressados pela questão; porém, pesquisadores da música folclórica espanhola e portuguesa, especialmente do flamenco, do fandango e de outros gêneros andaluzes, têm se dedicado ao estudo das características ibéricas de sua música, características que a tornam tão exótica e emocionante para ouvintes e artistas não latinas como eu. ${ }^{7}$ Essa situação levou W. Dean Sutcliffe (2003) a abrir seu brilhante estudo sobre as sonatas de Scarlatti com uma afirmação surpreendente: “Domenico Scarlatti não pertence". Scarlatti não pertence a um país nem a um domínio estilístico estável do cânone ocidental. E assim, como convém à sua incompatibilidade, Sutcliffe insere o compositor na única categoria que ele pode criar com convicção, mas com ironia: na de "Figura Histórica Interessante" (p. 1). Em resumo, a única informação confiável sobre Scarlatti, como um compositor e uma pessoa imaginada ou persona, deve ser extraída de suas aproximadamente 555 obras curtas em forma binária e movimento único, transcritas por copistas, talvez sob sua supervisão, e eventualmente abrigadas em Veneza e Parma - em outras palavras, de suas próprias sonatas. ${ }^{8}$

O título deste artigo demonstra que tomei a liberdade de caprichosamente inventar uma nova categoria para o nosso compositor: "Artista Fugidio". 9 Se ele realmente queria ou não "fugir" tão drasticamente da atenção de historiadores e biógrafos, nunca saberemos. Mas do eminente musicólogo Malcom Boyd, temos

\footnotetext{
7 Por exemplo, vide Clark (1976; 2000); Puyana (1988); e Fadini (2008).

8 Para um relato completo das fontes primárias da maior parte das sonatas de Scarlatti, copiadas na Espanha entre 1742 e 1757 e levadas por seu amigo castrato Farinelli da Espanha para a Itália, vide Boyd (1987, cap. 8, "Keyboard Works"). Boyd também investiga grandes coleções secundárias, atualmente abrigadas em bibliotecas de Münster e Viena, outras fontes e edições do século XVIII de menor importância, edições do século XIX e manuscritos descobertos em 1986. O esforço para capturar uma imagem "completa" de Scarlatti como compositor se torna ainda mais intimidante quando consideramos que, como diz Boyd, "seria difícil nomear outro compositor da estatura de Domenico Scarlatti que tenha adotado e dominado, como ele o fez, três estilos musicais bastante diferentes e contrastantes": o estilo vocal de suas óperas, oratórios, cantatas e serenatas, a "polifonia a cappella (ou acompanhada por contínuo) 'alla Palestrina'" da maior parte de sua música sacra existente e o "surpreendentemente original [. . . estilo instrumental" das próprias sonatas para cravo (1987, p. 112). Este esforço vai muito além do escopo deste artigo.

9 N.T.: Ao longo do texto, a autora utiliza a palavra scape em diversos momentos, fazendo referência ao termo Scape Artist, traduzido aqui como Artista Fugidio. Tendo em vista as possíveis nuances de significados das palavras escapar e fugir, esta tradução busca, sempre que possível, manter o pararelismo explorado no texto original.
} 
o seguinte: “Chega a parecer que Domenico Scarlatti contratou um agente para remover todos os traços de sua carreira do olhar da posteridade [. . .] diaristas e correspondentes contemporâneos dificilmente teriam sido menos informativos se tivessem se unido em uma conspiração de silêncio contra ele" (1985, p. 589). Para teóricos e analistas de sua música, a fuga do compositor de uma classificação estilística é tão intrigante quanto. Podemos aplaudir isto como uma jogada inteligente de sua parte, dada a nossa atual insatisfação generalizada com categorias estilísticas e fronteiras artificiais entre períodos históricos. Sutcliffe nos lembra do clichê de que Scarlatti "tem um pé no Barroco e outro na era Clássica"; o fato de ele "realmente não pertencer" a nenhum dos dois períodos pode ser usado em prol dele mesmo. Uma premissa central do estudo de Sutcliffe é que o compositor era especialmente consciente dos estilos contemporâneos e "agudamente consciente" de seu próprio. Sutcliffe propõe até "uma relutância da parte do compositor de se identificar com qualquer modo de discurso nas sonatas para teclado, para tornar o fato de não pertencer, ou não querer pertencer, uma virtude" (2003, p. 8).

Na ausência de uma categoria estilística convincente para Scarlatti - pósBarroco? Pré-Clássico? Galante? Transitório? - Sutcliffe recorre à expressão adequada "estilo misto" (2003, p. 79, 322 e passim). Porém, em termos claros, ele entrega o jogo eventualmente; por duas vezes em seu livro, quase repetições literais, ele afirma que "é axiomático para este estudo que muito sobre as sonatas de Scarlatti seja considerado à luz do estilo Clássico, apesar de todos os fatores que podem nos fazer resistir a essa classificação" (p. 323; vide também p. 79). Uma propriedade das sonatas surge como justificativa primária para esse axioma: a pronunciada "variedade de material musical" (ibid.). Em contraste com a "unidade e coerência" da música Barroca (p. 322), a emergência de uma variedade textural, temática, harmônica, sintática e "tópica" no século XVIII constitui uma novidade genuína. Como exemplos dessa nova abordagem compositiva, as sonatas de Scarlatti "devem ser apreciadas, em parte, como agentes de uma transformação e seu compositor como um inovador" (p. 323). A descrição de Giorgio Pestelli do contraste temático de Scarlatti antecipa a de Sutcliffe e, de alguma maneira, dá cor à metáfora do "artista fugidio", que tenta capturar a atmosfera teatral e até mesmo circense de tantas sonatas. Pestelli diz: "A sonata se torna um palco no qual os diversos atores, assim como os temas da sonata com seus diferentes caracteres, podem realizar ações imprevistas e 
imprevisíveis. É realmente um novo modo de pensar em música que surge pela primeira vez" (1985, p. 84).

Quanto mais estudo essas sonatas, mais me aproximo da ideia de Sutcliffe de que muito se pode ganhar se as examinarmos à luz de técnicas compositivas da segunda metade do século XVIII. No entanto, desejo ir além do aspecto óbvio de sua variedade tópica - uma caracterização tradicional das diferenças entre o Barroco e os estilos seguintes. Inicio investigando a questão da forma como um todo - isto é, a "forma sonata Scarlatti", exibida em quase todas as suas peças. Em seguida, volto a minha atenção ao tratamento típico e, muitas vezes, excepcional que o compositor dá às duas partes da forma e às suas passagens interiores. Ao longo do caminho, espero poder me permitir o esforço de desenvolver o tema do "artista fugidio" a partir de uma perspectiva musical e biográfica. Argumentarei, por exemplo, que a partir das perspectivas da sintaxe fraseológica, do plano harmônico e, especialmente, das estratégias cadenciais, ele emprega mecanismos de escape característicos da música do fim do século XVIII-evasões supreendentemente perturbadoras de certas expectativas. ${ }^{10}$ Porém, as anotações analíticas de tipo schenkeriano adicionadas aos meus exemplos, outra arena analítica da qual Scarlatti surpreendentemente escapou, podem ajudar a demonstrar de forma implícita que estruturas fundamentais tonais geralmente dão coerência à deslumbrante variedade de materiais díspares utilizados pelo compositor. ${ }^{11}$ Não desejo transportar o estilo de Scarlatti para o domínio das

10 Para Zbikowski (2010), as "rupturas sintáticas" (realizadas especialmente através do uso de empréstimo modal, dissonâncias não resolvidas, síncopes e cadências de engano) da Sonata em Lá maior, K. 208, de Scarlatti, servem como "análogos sônicos para processos dinâmicos, os quais podem ser simplesmente correlacionados a emoções": “O que é excepcional é a certeza com que Scarlatti concebe tais rupturas, demonstrando um domínio equivalente ao de um ator que dá vida a uma personagem que, para alguns, seria a base para pouco mais do que uma atuação rotineira" (p. 53-54).

${ }^{11}$ Em sua resenha do livro Advanced Schenkerian Analysis: Perspectives on Phrase Rhythm, Motive, and Form (2012), de David Beach, Berry observa que "compositores do panteão de Schenker que não estão representados" no estudo de Beach "incluem C. P. E. Bach, Handel, Mendelssohn e Domenico Scarlatti (sendo o último destes quase sempre negligenciado em livros de texto schenkerianos)" (2012, p. 165). O próprio Schenker publicou análises de duas sonatas de Scarlatti - K. 9, em Ré menor, e K. 13, em Sol maior; disponíveis em Schenker (1994), com tradução para o inglês de Ian Bent. Com relação ao país a que Scarlatti "pertence", pode-se mencionar que Schenker chegou perto de recebê-lo no território alemão: "A profundidade da música de Scarlatti, o sabor da terra que permeia suas diminuições florescentes, coloca-o muito próximo dos grandes mestres da música alemã" (1994, p. 67). 
MUSICA THEORICA Revista da Associação Brasileira de Teoria e Análise Musical 2020, v. 5, n. 1, p. 1-52 - Journal of the Brazilian Society for Music Theory and Analysis@ TeMA 2020 - ISSN 2525-5541

técnicas Clássicas tardias; antes, desejo simplesmente usá-las como medida para explorar o que torna sua música diferente de qualquer outra. Abordarei cinco de suas sonatas aqui, escolhidas por suas características representativas e únicas, e por admirá-las muito.

\section{A "forma sonata Scarlatti"}

Considerando que o termo forma sonata tornou-se inextricavelmente associado à forma sonata Clássica do fim do século XVIII, já completamente desenvolvida, (exposição, desenvolvimento e recapitulação), o próprio nome que Scarlatti deu a quase todas as suas obras para teclado-"sonata"-exige, regularmente, defesa e esclarecimento. Em seu estudo inovador sobre o compositor, Ralph Kirkpatrick inicia o capítulo 11, "A Anatomia da Sonata de Scarlatti", com a seguinte declaração: "Provas fossem necessárias, nada provaria melhor a vitalidade das sonatas de Scarlatti do que sua resistência à análise ou classificação sistemática" ([1953] 1983, p. 251). ${ }^{12}$ Apesar desta resistência, sua extensa "anatomia" é, obviamente, uma "análise sistemática" - a primeira desse tipo e o ponto de partida para estudos posteriores da forma; mas ele precisa de apenas uma frase para acertar em cheio a diferença essencial entre uma sonata de Scarlatti e uma sonata Clássica, e aqui está a frase: "A sonata de Scarlatti é mais ou menos como uma sonata clássica que começa a obedecer as regras [Clássicas] apenas com o segundo tema e os temas de fechamento, em outras palavras, [apenas] após o estabelecimento definitivo da tonalidade que encerra a obra" ([1953] 1983, p. 253-254). Kirkpatrick descarta firmemente o termo exposição para a primeira metade da forma de Scarlatti, e sustenta que é "um erro falar de primeiro e segundo temas, ou mesmo de tema principal e tema subsidiário em Scarlatti" (p. 253).

Nada comparável à profundidade analítica e à pesquisa biográfica imaginativa da monografia de Kirkpatrick sobre as sonatas apareceu em inglês até a publicação do livro de Sutcliffe, 50 anos depois, e, a essa altura, Sutcliffe estava preparado para abandonar a maioria dos termos formais "anatômicos" de

\footnotetext{
${ }^{12}$ A afirmação de Kirkpatrick continua da seguinte maneira: “As forças que moldam as sonatas de Scarlatti estão continuamente influenciando e se opondo umas às outras a tal ponto que é quase impossível estabelecer regras que o próprio Scarlatti não quebre ou definir categorias que ele mesmo não destrua" ([1953] 1983, p. 251).
} 
Kirkpatrick em prol de termos mais amplos e mais ousados, alguns deles dando destaque à sua afirmação de que a forma de Scarlatti dirige o olhar para um "estilo de sonata" de um período posterior ao seu. A "forma binária equilibrada" [balanced binary form] - um termo introduzido por Douglass M. Green (1979, p. 78-79) - é a categoria geral escolhida por Sutcliffe para as formas bipartidas de Scarlatti. Ele parece assumir que sabemos algo sobre esse tipo de forma, em oposição às formas "binária simples" e "binária com recapitulação" [rounded binary], pois coloca sua primeira descrição em parênteses: “(Na forma binária equilibrada, o material que encerra cada metade é correspondente e, portanto, cria uma rima estrutural)" (2003, p. 320). Sutcliffe está preocupado em combater acusações a Scarlatti que classifiquem o uso repetido da forma como "pouco arrojado", e se incomoda com o que chama de "as principais narrativas da historiografia da música do século XVIII", nas quais há um "desenvolvimento inexorável em direção à forma sonata" - o estilo da "sonata Clássica que atua como a terra prometida" (p. 320). ${ }^{13}$ Entretanto, ele reconhece o uso cauteloso de "parte da terminologia característica da forma sonata", particularmente da seguinte maneira: "Scarlatti tem segundos sujeitos, mas geralmente não tem primeiros sujeitos" (p. 324). O argumento de Sutcliffe é que os materiais de abertura quase nunca são "recapitulados", referindo-se ao "retorno duplo" que define a estrutura formal da sonata Clássica. E, no entanto, os "segundos sujeitos", ouvidos pela primeira vez em uma região tonal diferente da tônica, quase sempre retornam ao final da segunda metade da forma transpostos para a tonalidade inicial. Para citar Sutcliffe novamente: "Ao garantir [. . .] que esse material seja apresentado sobre a tônica ao final, o compositor está, de fato, articulando os mesmos princípios do argumento harmônico que são evidentes na forma binária com recapitulação e na forma sonata" (2001, p. 4).

A forma utilizada por Scarlatti é, então, um tipo de forma sonata? Em 2003, Sutcliffe não estava disposto a dar esse salto, apesar de elogiar Michael Talbot (1990) por fazê-lo. ${ }^{14}$ Com a publicação do livro Elements of Sonata Theory, James

\footnotetext{
${ }^{13}$ Vide também Sutcliffe (2001), onde o autor expõe claramente as características distintivas da forma "binária seccional", "binária contínua simples", "binária equilibrada", "binária com recapitulação" (com seu "retorno duplo") e "binária seccional com recapitulação" (cuja primeira parte termina na tônica inicial); aqui ele faz referência a Green (1979).

${ }^{14}$ De Talbot (1990): “[A] barreira real para a identificação da estrutura da sonata em Scarlatti como uma versão inicial específica da forma sonata não é tanto analítica, mas histórica; a própria música
} 
MUSICA THEORICA Revista da Associação Brasileira de Teoria e Análise Musical 2020, v. 5, n. 1, p. 1-52 - Journal of the Brazilian Society for Music Theory and Analysis@ TeMA 2020 - ISSN 2525-5541

Hepokoski e Warren Darcy pareceriam ter solucionado a questão. Como se sabe, os autores defendem cinco "tipos de forma sonata" distintos; o "Tipo 2" é o tipo de Scarlatti. Hepokoski e Darcy descrevem a versão de Scarlatti do Tipo 2, sem divergir radicalmente dos relatos formais de Kirkpatrick, Boyd e Sutcliffe, todos eles citados. No entanto, o que torna a identificação da forma sonata de Scarlatti tão diferente, no caso de Hepokoski e Darcy, é o uso destemido da "terminologia da forma sonata". A Figura 1 reproduz o "Padrão Básico da sonata Tipo 2" de Hepokoski e Darcy.

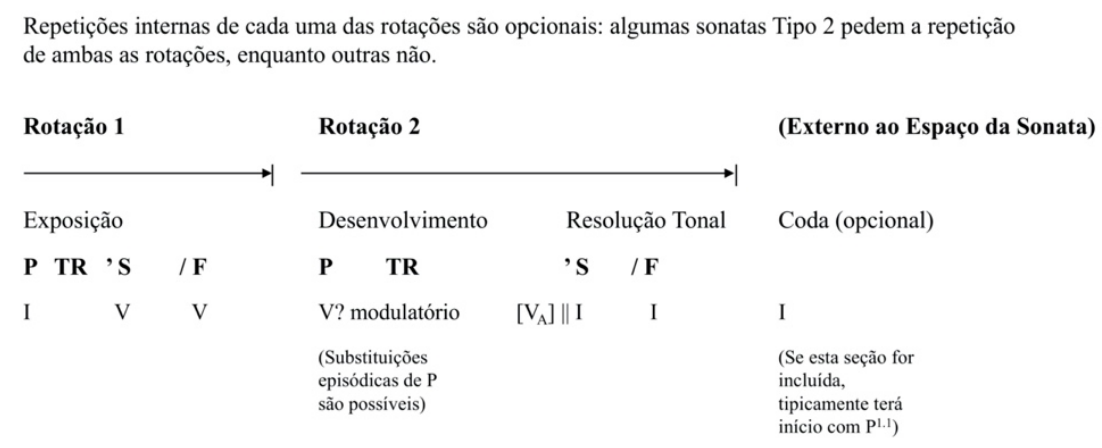

Figura 1: Esquema formal da "sonata Tipo 2" (Hepokoski; Darcy 2006, p. 354)

Central para a definição da forma apresentada pelos autores, e difundido em todo o texto como uma característica determinante das diversas formas de sonata, é o princípio arquitetônico de rotação: a "reciclagem, por uma ou mais vezes, - com as devidas alterações e ajustes - [de] um padrão temático referencial estabelecido como uma sucessão ordenada no início da peça" (Hepokosky; Darcy 2006, p. 611). Na sonata Tipo 3 - a "forma sonata Clássica" de Kirkpatrick e Sutcliffe -, três rotações geralmente se fazem presentes: a exposição estabelece o padrão rotacional, e às vezes o desenvolvimento e quase sempre a recapitulação reciclam este padrão. A forma sonata Tipo 2 possui apenas uma "rotação dupla": ela conta com "dois ciclos ao longo da estrutura principal", ciclos que consistem em "P TR ' S / F"15 ou zonas primárias, de transição, secundária e de fechamento

\footnotetext{
apresenta características que, no todo, são muito mais consonantes com o princípio e a prática da sonata do que com a forma binária simétrica empregada por Bach, Rameau e Vivaldi [. . .] mas o não posicionamento de Scarlatti na linha principal do desenvolvimento histórico inibe esse reconhecimento" (apud Sutcliffe 2003, p. 323).

${ }^{15}$ N.T.: A inicial F substitui a inicial C, adotada por Hepokoski e Darcy (2006) como sigla para o termo closing zone.
} 
(p. 353). ${ }^{16}$ Esse é o padrão normalmente estabelecido nas primeiras partes das sonatas de Scarlatti, que modulam comumente para a dominante ou mediante; assim, as primeiras metades das formas de Scarlatti se comportam de maneira semelhante ao que chamamos de exposição nas sonatas do fim do século XVIII, geralmente com repetição. Dessa forma, e com todo o respeito a Kirkpatrick, Hepokoski e Darcy não hesitam em utilizar o termo exposição. A segunda metade da forma, também repetida, realiza a segunda rotação: esta se inicia como um "espaço de desenvolvimento" (caracterizado por Kirkpatrick como "digressão"), normalmente na tonalidade confirmada ao fim da exposição, e apresenta um retorno explícito aos materiais de abertura da sonata ou uma "elaboração típica de desenvolvimento" destes materiais: "Um pouco depois, essa referência à zona temática primária fora da região da tônica se amplia para uma atividade de desenvolvimento mais explícita e modulante (geralmente baseada em materiais de $\mathrm{P}$ e/ou TR)" que se dirige eventualmente ao que os autores chamam de ponto crux, um termo que eles tomam emprestado de Kirkpatrick, com alguma modificação. Este é o ponto onde "os compassos correspondentes" aos materiais temáticos secundários ou de fechamento da exposição, ou que os antecedam brevemente, podem ser identificados, permitindo o rastreamento do retorno destes mesmos materiais - isto é, aqueles que "rimam", agora na tonalidade inicial (p. 353). ${ }^{17}$

\footnotetext{
${ }^{16}$ A ideia de "rotação" na forma sonata tem sido frequentemente adotada pelos defensores da Teoria da Sonata de Hepokoski e Darcy, mas não está livre de críticas. Por exemplo, Wingfield (2008, p. 13) cita a "infinidade de modificações" criadas pelos autores para explicar "o fato de que relativamente poucos desenvolvimentos percorrem literalmente os materiais da exposição na ordem original": "desenvolvimentos com semi-rotações, rotações truncadas, rotações com substitutos episódicos que 'sobrescrevem' alguns dos elementos individuais esperados, rotação com interpolações recém-incluídas, digressões internas da linha rotativa em vigor, reordenamentos ocasionais dos módulos e outros casos similares" (Hepokoski; Darcy 2006, p. 613). Wingfield também pergunta "por que a rotação do desenvolvimento deve ser equiparada à rotação expositiva", quando "a sucessão expositiva de unidades 'estáveis' [tight-knit] e 'instáveis' [loose-knit] (termos de Caplin) bem como seus padrões de estabilidade e instabilidade texturais e tonais são inteiramente diferentes daqueles de um desenvolvimento", onde a "característica determinante [. . .] é, de fato, o contraste, normalmente na forma de uma organização mais flexível, dominada pela fragmentação e progressão sequencial" (2008, p. 14).

${ }^{17}$ Embora Hepokoski e Darcy apliquem o termo exposição à primeira parte da sonata Tipo 2, eles rejeitam a ideia de que uma recapitulação possa começar com o retorno de materiais temáticos secundários na segunda parte: conforme descrito acima, a segunda rotação começa no início da
} 
MUSICA THEORICA Revista da Associação Brasileira de Teoria e Análise Musical 2020, v. 5, n. 1, p. 1-52 - Journal of the Brazilian Society for Music Theory and Analysis@ TeMA 2020 - ISSN 2525-5541

Para aqueles que abordaram as sonatas de Scarlatti em grande medida a partir de seus próprios pontos de vista, talvez o aspecto mais informativo do capítulo sobre a sonata Tipo 2 de Hepokoski e Darcy seja o esclarecimento de que essa forma dificilmente é exclusiva de Scarlatti: "A estrutura de Tipo 2 se tornou uma opção compositiva comum da forma sonata em meados do século XVIII", praticamente "coexistindo" com a emergente estrutura de Tipo 3 (2006, p. 359 e 358). Os autores se referem a exemplos de vários gêneros de compositores tão diversos como Sammartini, Stamitz, C. P. E. Bach, seu irmão mais novo Johann Christian, Wagenseil, a primeira fase de Dittersdorf, a primeira de Haydn e, sim, Mozart, especialmente nas obras compostas até aproximadamente seus 16 anos de idade (p. 359, 362-363). No início da década de 1770, a sonata Tipo 2 havia começado a desaparecer, sendo substituída pela de Tipo 3. Mas Hepokoski e Darcy argumentam que o Tipo 2 "nunca desapareceu completamente"; eles citam exemplos que vão de Weber, Schubert e Mendelssohn a Sibelius, Tchaikovsky e Mahler, e, é claro, incluem Chopin (p. 363-364)-que adorava as sonatas de Scarlatti e que presumivelmente utiliza o Tipo 2 nos primeiros movimentos de suas duas sonatas maduras para piano, bem como em sua sonata para violoncelo. ${ }^{18}$

Finalmente, qual é a relevância disso tudo para os analistas que se dedicam às sonatas de Scarlatti? Sabemos, ao menos, que as únicas sonatas que

segunda parte, anulando assim a possibilidade de outro "começo" no momento em que retornam os materiais secundários; em resumo, "sonatas Tipo 2 não possuem recapitulações" (2006, p. 354).

18 Assim como o conceito de "rotação", a validade da categoria Tipo 2 também tem sido questionada, principalmente com respeito à sua sobrevivência em algumas obras do século XIX, e particularmente nos casos do "Tipo 2" em que "os últimos estágios da segunda parte [...] interpolam material temático primário na tônica antes ou depois do material de fechamento" (Wingfield 2008, p. 19). Hepokoski e Darcy rejeitam enfaticamente a categoria consagrada da "recapitulação espelhada" ou "reversa", "interpretada mais precisamente como expansões de estruturas do Tipo 2 nas quais o aparecimento tardio de P geralmente adquire a qualidade de coda da segunda rotação ou de uma interpolação tardia à maneira de uma coda, já como parte da zona de fechamento (F)" (2006, p. 369). Por razões diferentes, Caplin também considera deficiente a ideia de uma recapitulação "reversa" nas formas Clássicas: quando ideias do tema subordinado surgem antes das do tema principal, "este [último] material é remodelado para atuar como um tema subordinado, exibindo assim dispositivos de afrouxamento associados a essa função" (2013, p. 509). Por outro lado, em vez de rejeitar a ideia da "recapitulação reversa", Wingfield prefere conceber certas obras do século XIX que exibem a chamada forma Tipo 2-por exemplo, os primeiros movimentos da Sonata $\mathrm{n}^{\mathrm{0}} 3$ de Chopin para piano e sua Sonata para Violoncelo-como obras que manifestam "um elemento primordial de diálogo com o modelo Tipo 3" (2008, p. 22). 
ele autorizou a publicação-as 30 sonatas dos Essercizi per gravicembalodeveriam haver sido concluídas em 1738, ano em que Scarlatti as dedicou ao Rei português, João; em 1757, ano de sua morte, cópias de todas as 555 sonatas já haviam sido feitas, embora não saibamos quando elas foram compostas. Muitas de suas peças podem facilmente haver sido compostas nas décadas de 1720 e 1730; neste caso, elas antecipariam o auge da forma sonata Tipo 2, dos 1740s aos 1770s. E, no entanto, mesmo um conhecimento superficial das obras para teclado no formato Tipo 2, escritas por outros compositores neste mesmo período, contraria a noção de que, estilisticamente falando, essas outras obras têm muito em comum com as sonatas de Scarlatti, exceto por sua estrutura formal. ${ }^{19}$ Consideremos essa observação através da análise de um dos Essercizi do compositor, a Sonata em Si menor, K. 27. O Ex. 1 apresenta a partitura da peça com anotações.

\section{K. 27 e o "estilo misto"}

Podemos notar que a sonata começa com uma troca imitativa bastante livre entre soprano e contralto, ao longo de uma progressão que prolonga a tônica. Baixo e tenor entram no compasso 3, agora completando brevemente uma textura a quatro vozes e conduzindo a uma cadência autêntica perfeita (CAP) na cabeça do compasso 4. Aberturas imitativas não rigorosas como esta são frequentes nas sonatas de Scarlatti; Sutcliffe associa essa e outras aberturas com o "estilo culto" [learned style] (2003, p. 153-154), geralmente vinculado ao "Barroco". Mas é difícil considerar o que se segue (c. 4-7) como "culto": aqui temos oitavas paralelas evidentes, ousadamente reforçadas pelos cruzamentos das mãos. O movimento descendente por graus conjuntos de $\hat{1}$ a $\hat{5}$ no soprano e no baixo conduz, por meio do tetracorde "lamento", ou "frígio", a uma potencial semi-cadência frígia (iv $\left.{ }^{6}-\mathrm{V}\right)$ no compasso 7; tal progressão tem sido associada especificamente ao "flamenco puro" e à típica cadenza andalusa. ${ }^{20}$ Seria difícil

\footnotetext{
${ }_{19}$ Para apenas alguns dos muitos exemplos de movimentos de sonata Tipo 2 de compositores da segunda metade do século XVIII, que não Scarlatti, vide: C. P. E. Bach, Sonata em Fá menor, Wq.63/6, H.75 (Probestuck 6, 1753), i; J. C. Bach, Sonata em Si, maior, op. 5/1 (1768), i; e Mozart, Sonata para piano em Mi, maior, K. 282, i (1774). Os movimentos de J. C. Bach e Mozart são mencionados em Hepokoski e Darcy (2006, p. 362).

${ }^{20}$ Fadini (2008) baseia-se na Teoría musical de la guitarra flamenca (1998), de Manuel Granados, para reunir evidências de que o tetracorde descendente lá sol fá mi serve como "base harmônica" (base
} 
MUSICA THEORICA Revista da Associação Brasileira de Teoria e Análise Musical 2020, v. 5, n. 1, p. 1-52 - Journal of the Brazilian Society for Music Theory

imaginar um contraste estilístico mais acentuado nos compassos 1-7 - uma "clara oposição de tipos sintáticos", como diz Sutcliffe (2003, p. 153).
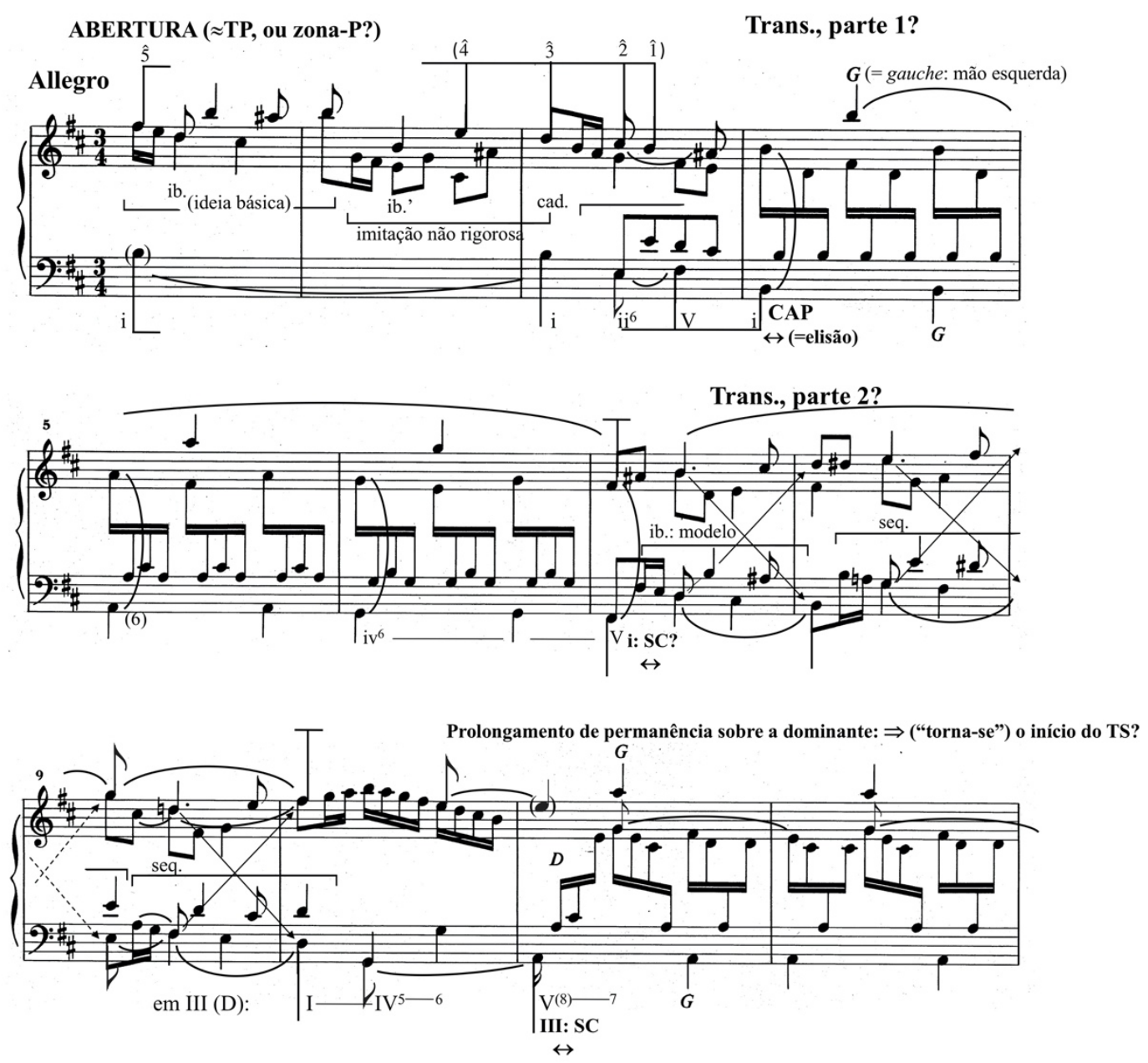

armónica) para o flamenco, e que a sucessão de acordes em quintas paralelas sobre este baixo descendente forma a típica cadenza andalusa. O objetivo final da progressão-aqui a dominante da cadência frígia-é conhecido na teoria do flamenco como "Tônica secundária" (Tónica secondaria), sendo o acorde de partida interpretado como a "Grande Tônica ou Tônica principal" (Grande Tónica ou Tónica principale) (p. 160). A passagem dos compassos 4-7, da K. 27 de Scarlatti, apresenta acordes de sexta descentes, em vez de tríades paralelas em posição fundamental, nos compassos 5 e 6; Fadini apresenta esta progressão como uma variante da cadenza andalusa em referência à K. 6 do compositor, compassos 18-25 (p. 163). Em ambos os casos, a progressão seria categorizada por Caplin como uma representante da sequência descendente por graus conjuntos; vide $n$. 34. 

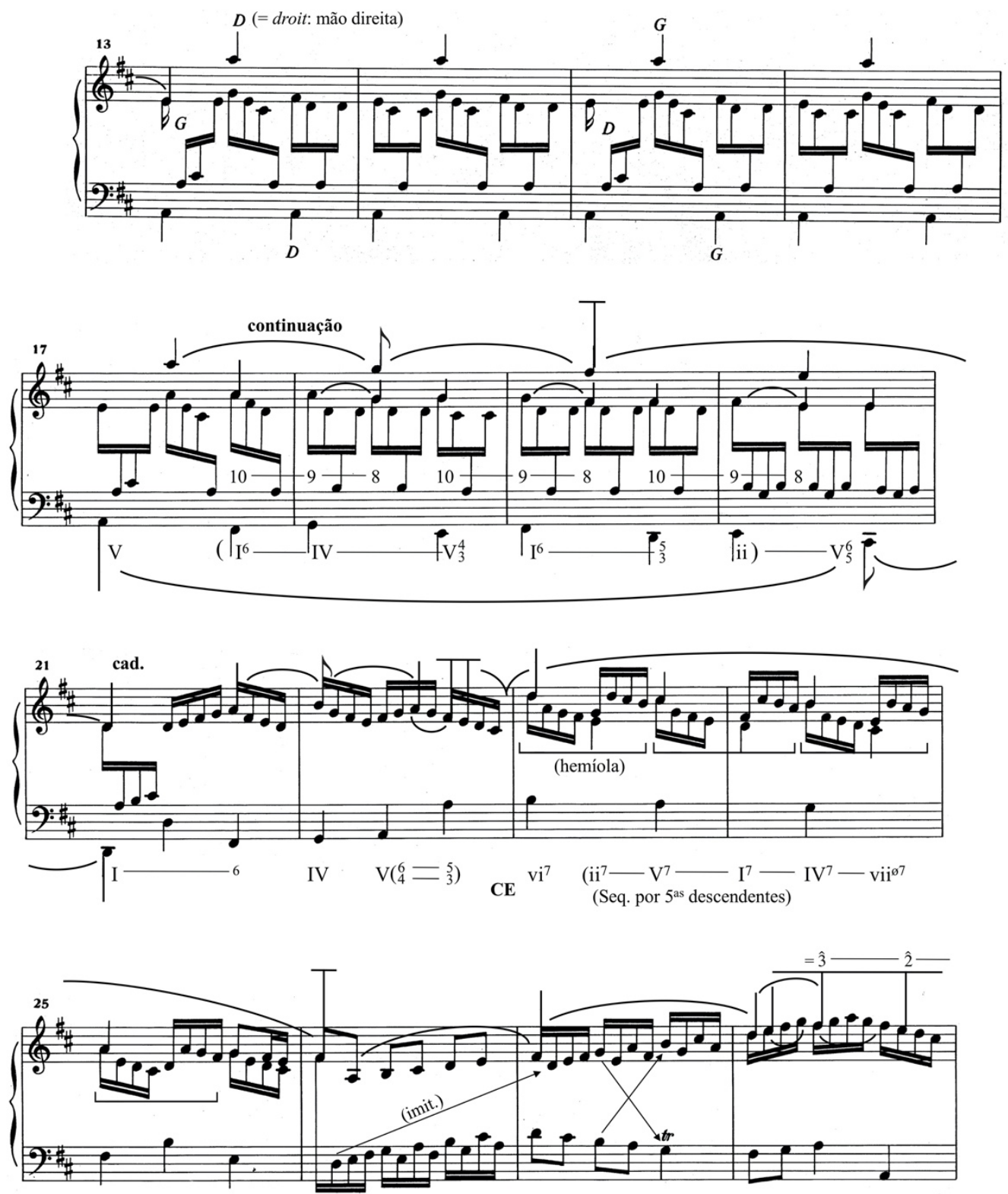

- iii $\left.^{7}\right) \quad \mathrm{vi}^{7}$

ii $^{7}\left(\right.$ vii $\left.^{7}\right)$ I

$\left(\mathrm{IV} \mathrm{V}_{2}^{4}\right) \quad \mathrm{I}^{6} \quad \mathrm{ii}^{6} \quad \mathrm{~V}\left(\begin{array}{c}6 \\ 4\end{array}{ }_{3}^{5}\right)$

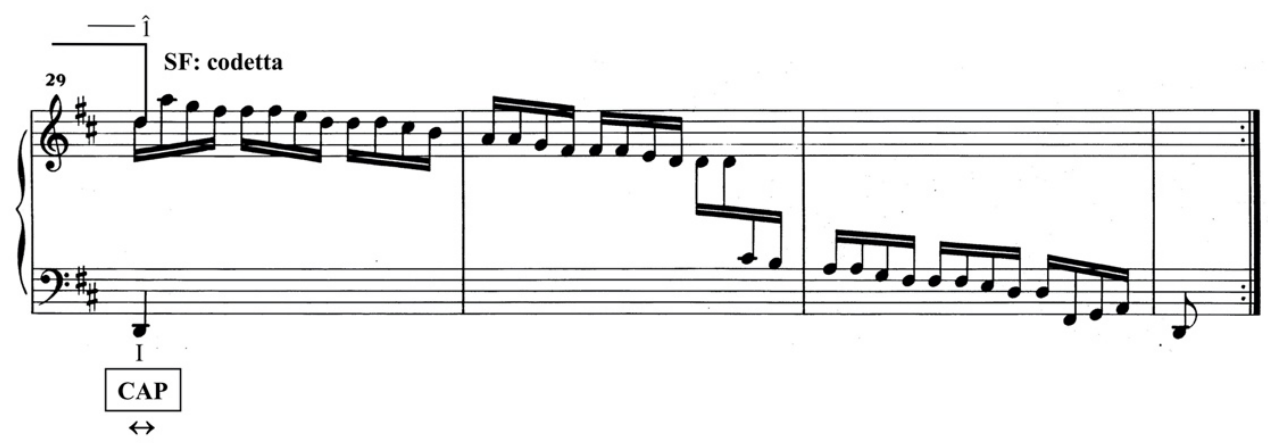

Exemplo 1: Domenico Scarlatti, Sonata em Si menor, K. 27, dos Essercizi per gravicembalo (1738), c. 1-32 
Certamente, a cadência frígia, com suas origens no canto medieval, está presente na música de inúmeros compositores anteriores e posteriores a Scarlatti. O Ex. 2 apresenta uma obra de 1732 do compositor napolitano, maestro e partimentista Francesco Durante (1684-1755), contemporâneo exato de Scarlatti, conforme extraído do tratado de Robert O. Gjerdingen (2007) sobre o estilo galante. $\mathrm{O}$ baixo de Durante compreende o tetracorde frígio descendente nos compassos 8-9, resumindo de maneira ordenada o descenso gradual mais abrangente criado pelo sujeito da fuga nos compassos 1-4 (vide hastes adicionadas); o objetivo cadencial frígio, no compasso 9, marca o fim da primeira exposição da fuga, com a resposta do sujeito à oitava sendo introduzida na voz mais grave no compasso 4. (Uma segunda exposição tem início sobre a dominante menor no compasso 10 e termina com a mesma aproximação à cadência frígia, transposta.) Um contralto "adicional" é introduzido para criar a suspensão do compasso 4, e então uma textura a três vozes emerge. Ao atingirmos a progressão frígia nos compassos 8-9, quatro vozes já estão em jogo, e elas parecem determinadas a evitar oitavas e quintas paralelas a todo custo, aproximando-se destes intervalos por movimento contrário. Comparativamente, as oitavas paralelas de Scarlatti soam estrangeiras, pelo menos em relação à língua franca de seus contemporâneos galantes, e como uma violação deliberada das regras contrapontísticas destes que ele certamente conhecia muito bem (vide novamente n. 3). ${ }^{21}$

\footnotetext{
${ }^{21}$ O exemplo de Gjerdingen (2007, p. 165, Ex. 11.44) inclui apenas os compassos 7-9 do Studio de Durante; o trecho aparece no capítulo intitulado "Clausulae" e serve como ilustração para os “Desfechos Característicos de um Tenor" - a clausula vera (c. 7-8) e sua variante frígia (c. 9).
} 

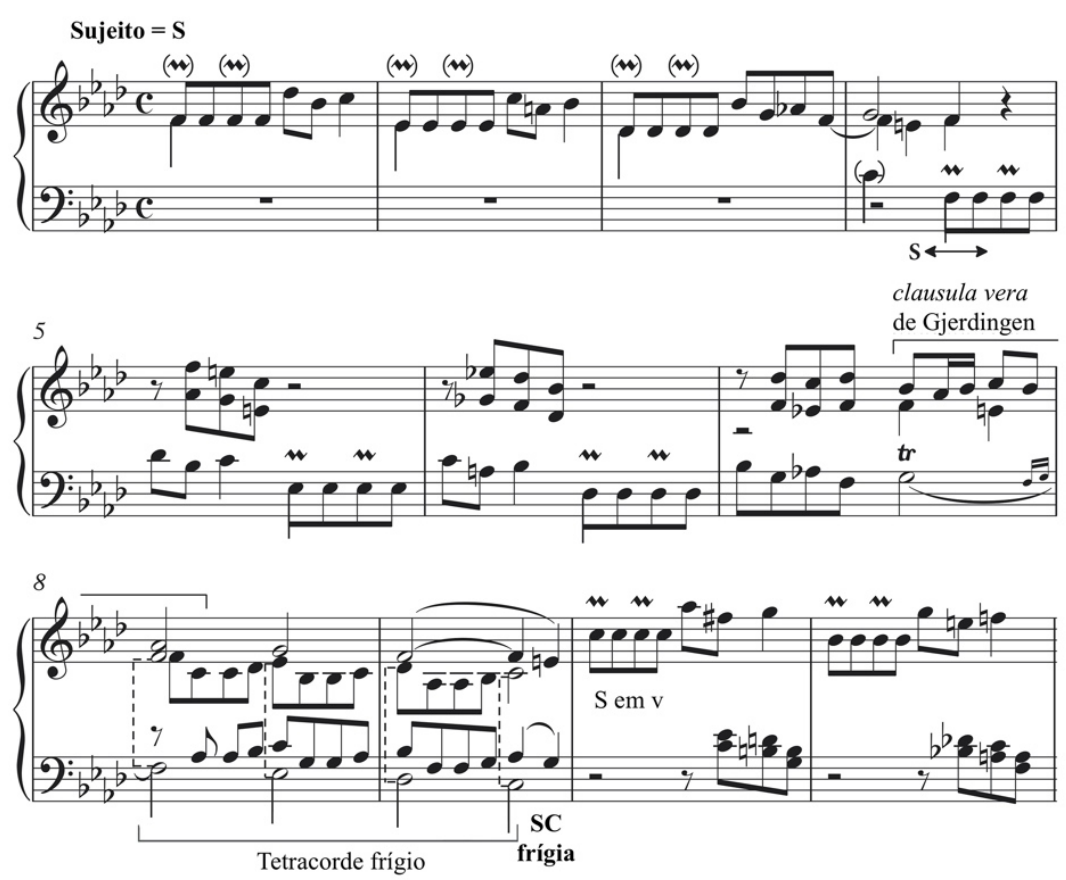

Exemplo 2: Francesco Durante, Studio no. 5, das Sei sonate per cembalo divisi in studii e divertimenti (1732), c. 1-11

Percebo a cadência do compasso 4 da K. 27 de Scarlatti como uma clara elisão (representada na partitura por $\leftrightarrow$ ): sua tônica cadencial serve, simultaneamente, como o início da frase seguinte. Tanto o cravista Scott Ross (1984-85, CD 2, faixa 8) quanto o pianista Murray Perahia (1997, faixa 17) parecem ouvir o mesmo; cada um à sua maneira, ambos tratam o início do compasso 4 como um fim e um novo início.

Podemos considerar a abertura da K. 27, compassos 1-4, como um "tema principal" (ou “zona $\mathrm{P}^{\prime}$ ), de acordo com a terminologia da sonata Clássica? Afinal, esta passagem, embora formada por apenas uma frase, realiza o papel de um "tema principal" ao estabelecer a tônica inicial e terminar com uma cadência nessa tonalidade. Além disso, minhas anotações analíticas propõem uma linha descendente completa ao estilo de uma Urlinie, partindo da nota primária 5 , Fá\#, compreendendo toda a extensão da frase. Mas lembre-se: esta abertura não retornará em sua forma e tonalidade originais para servir como o início de uma recapitulação com "retorno duplo". É provavelmente por isso que Kirkpatrick e Sutcliffe se referem a esta abertura simplesmente como uma abertura. Marco Moiraghi, escrevendo em italiano, utiliza inizio (2014, p. 158 e passim). Em contraste, o novo padrão de acompanhamento em semicolcheias contínuas e a 
MUSICA THEORICA Revista da Associação Brasileira de Teoria e Análise Musical 2020, v. 5, n. 1, p. 1-52 - Journal of the Brazilian Society for Music Theory and Analysis @ TeMA 2020 - ISSN 2525-5541

nova textura que se iniciam no compasso 4 geram um "ganho de energia" 22 semelhante ao de muitas transições de obras em forma sonata do fim do século XVIII. Não há modulação até a aparente semi-cadência (SC) na tonalidade inicial articulada no compasso 7, que parece ser invalidada quando a música avança com o retorno da ideia inicial na mão esquerda. ${ }^{23}$ Duas repetições sequenciais do gesto inicial nos conduzem à mediante-Ré maior-e, em seguida, a uma semicadência articulada por sua própria dominante no compasso 11. Se, neste momento, houvesse uma pausa e um silêncio, a transição de Scarlatti poderia haver terminado com aquilo que Hepokoski e Darcy chamam de "cesura medial" $(\mathrm{CM}){ }^{24}$

Ao invés disso, o que sucede oferece um belíssimo exemplo da notória preferência de Scarlatti pela repetição imediata, incessante. A ideia melódica de um compasso realizada sobre o novo pedal de dominante no compasso 11, com arpejos insistentes da tétrade de dominante, apresenta o recorrente movimento melódico de terça descendente, $\mathrm{Sol}-\mathrm{Fá} \#-\mathrm{Mi}$; trata-se de uma reinterpretação harmônica do movimento de terça descendente da própria ideia básica inicial, primeiro em semicolcheias (c. 1, Fá\#-Mi-Ré), depois em semínimas, percebido com maior clareza no baixo dos compassos 9 e 10. (Quando a ideia básica aparece nos compassos 1 e 2, Scarlatti suprime a nota Si que completaria o movimento de terça descendente na voz interna no compasso 2; sua chegada sendo adiada até o segundo tempo deste compasso). ${ }^{25}$ Convido os ouvintes a contarem o número de ocorrências dessa única ideia, começando no compasso 11 . O número mágico será sete, e não o que provavelmente seria esperado, digamos, uma unidade regular de quatro ou seis compassos. A dificílima troca de papéis nos

\footnotetext{
${ }^{22}$ Hepokoski e Darcy (2006, p. 93 e passim). Vide também Hepokoski (2009, p. 194). Caplin diz que "as transições tendem a apresentar uma continuidade dos padrões de duração, uniformidade de combinações texturais e níveis dinâmicos relativamente estáveis. E juntos, esses parâmetros projetam uma qualidade direcional mais contínua, a sensação de que a música está finalmente avançando" (2010, §9).

${ }^{23}$ Caplin poderia argumentar que a primeira parte de uma transição não modulante tem início no compasso 4, seguida por uma segunda parte modulante que se estende da SC do compasso 7 à SC na tonalidade da mediante no compasso 11.

${ }^{24}$ Hepokoski e Darcy (2006, p. xxvi, 12, 17 [fig. 2.1] e cap. 3, "The Medial Caesura and the Two-Part Exposition", p. 23-50).

${ }^{25}$ Sutcliffe tece comentários sobre essa e outras "negações da propriedade da condução de vozes" em K. 27 (2003, p. 154).
} 
cruzamentos das mãos - primeiro com a mão esquerda e depois com a direitaclaramente auxilia o intérprete a coreografar um padrão de dois compassos ao longo do trecho. Para a persona acrobata de Scarlatti, essas trocas precisam ser vistas, podendo até auxiliar o artista a contar até sete $(2+2+2+1)$; mas, nas gravações, as trocas mal podem ser percebidas, pois as notas são sempre as mesmas. ${ }^{26}$ Repetições aparentemente intermináveis como estas, evidentes em muitas de suas sonatas, têm sido fonte de espanto, senão de críticas. Para Pestelli, neste caso, o "furor reiterativo, através do qual o tempo para, por assim dizer, oscila entre um gosto hedonista que se alegra em seus poderes e uma sensibilidade que é surpreendida pelas possibilidades do mundo dos sons" (1967, p. 146). Ou, como Sutcliffe coloca, citando Pestelli, o "hedonismo" do compositor sugere "uma incapacidade ou falta de vontade de ser racional e comedido no prazer de alguém, de saber instintivamente quando já basta" (2003, p. 154). Como alternativa, talvez pudéssemos pensar em Scarlatti como um hipnotizador: ele nos conduz a um estado inconsciente, despertando-nos gentilmente apenas quando o padrão finalmente cessa.

Em nossa primeira audição da peça, e talvez mesmo em audições posteriores, provavelmente interpretaríamos a função formal deste longo trecho como um prolongamento pós-cadencial (SC) de "permanência sobre a [nova] dominante" [post-half-cadential "standing on the [new] dominant"] (a "tranca de dominante" [dominant lock] de Hepokoski e Darcy); Como tal, o trecho seria provavelmente suficiente para William E. Caplin interpretá-lo como a marca do fim de uma transição de uma "exposição em duas partes", termo de Hepokoski e Darcy (Caplin 1998, p. 16 e 131-135). Como não houve uma cesura medial, Hepokoski e Darcy possivelmente considerariam esta exposição como "contínua", e não em "duas partes": "Se não há uma cesura medial, não há um tema secundário" (2006, p. 52). Mas talvez eles não se pronunciassem contra a noção de uma "zona temática secundária" incipiente aqui especialmente porque, como um

\footnotetext{
${ }^{26}$ As indicações de Scarlatti para as mãos foram reproduzidas por Kenneth Gilbert (ed., 19711984) aqui e ao longo de sua edição, sendo " $\mathrm{G}$ " para gauche, mão esquerda, e " $\mathrm{D}$ " para droit, mão direita. Um leitor anônimo propôs que é possível ouvir os difíceis cruzamentos de mãos na gravação de Ross (1984-1985): "a troca de mãos leva algum tempo para alguns artistas". Eu ouço apenas um microssegundo adicional, e isso somente no retorno do prolongamento da dominante na segunda metade da sonata; encorajo outros a ouvirem a interpretação de Ross dando atenção a este efeito.
} 
MUSICA THEORICA Revista da Associação Brasileira de Teoria e Análise Musical 2020,

v. 5, n. 1, p. 1-52 - Journal of the Brazilian Society for Music Theory and Analysis@ TeMA 2020 - ISSN 2525-5541

tema secundário Clássico, este é o material destinado a retornar na tonalidade inicial na segunda metade da forma. E, no entanto, se desejamos reivindicar a presença de um "tema secundário", onde ele começa, e onde ele termina? Claramente, a fronteira entre a função de transição e a função de tema secundário, frequentemente (mas nem sempre) evidenciada por vários meios nas formas Clássicas de sonata, é obscurecida aqui, e esse é o caso da maioria das sonatas de Scarlatti, incluindo as outras quatro sonatas a serem consideradas abaixo.

O elusivo sétimo compasso do prolongamento da dominante conduz diretamente ao que deve ser considerado uma continuação: o acorde $\mathrm{I}^{6}$, na anacruse do compasso 18, dá início a uma passagem pseudossequencial de quatro compassos-não com um padrão harmônico estritamente sequencial (vide minha análise com números romanos), mas com um novo padrão intervalar linear descendente que controla a passagem. Observe que as suspensões 9-8 mal são capazes de romper as oitavas paralelas, com os cruzamentos das mãos reforçando-as novamente, assim como antes. Em suma, temos aqui uma função média e não inicial-o que não é incomum para temas secundários no repertório Clássico, mas que, neste caso, poderia levar Caplin a propor que o tema subordinado realmente tem início com o prolongamento de permanência sobre a dominante dos compassos 11-17. Em outras palavras, este seria, para Caplin, o caso de um tema subordinado que "não possui uma função inicial", tal como uma apresentação; um prolongamento de permanência sobre a dominante substituiu esse tipo de função. ${ }^{27}$ Eu gostaria de ajustar tal visão, sugerindo que, a partir de uma perspectiva que considere nossa própria experiência da obra, o prolongamento da dominante só poderia "tornar-se" o início de um possível

\footnotetext{
${ }^{27}$ Vide Caplin (1998, p. 113-115; 2013, p. 393); vide também Caplin e Martin (2016). Como exemplos de temas subordinados que começam com um prolongamento de permanência sobre a dominante, Caplin e Martin citam o primeiro movimento do Quarteto de Cordas de Mozart em Mi, maior ("Hunt"), compassos 34-54, e fornecem uma lista de outros casos (2016, p. 18 e 35-36). Como uma visão alternativa, Caplin propôs a mim que a SC e a subsequente permanência sobre a dominante nos compassos 11-17, na Sonata K. 27 de Scarlatti, sejam concebidas, primeiramente, como o fim da transição e, em seguida, sejam reinterpretadas $(\Rightarrow)$ como uma SC "interna" + "permanência", ambas como parte de um tema subordinado que se funde com a transição; exemplos desse tipo de interpretação são fornecidos em Caplin e Martin (2016, p. 36). Eu respeitosamente rejeito essa visão. Se a transição de Caplin (bipartida) tiver início no compasso 4 (vide n. 23), uma fusão entre TR/TS [Transição/Tema Subordinado] cobriria o espaço de toda a exposição, com a exceção dos compassos 1-4 e da codeta; não haverá o encerramento de um tema secundário até o final da exposição, como veremos.
} 
tema secundário "retrospectivamente" ${ }^{28}$ Considerando a pontuação final do tema, uma ideia cadencial de dois compassos promete um desfecho no compasso 23, mas a cadência é evadida (CE). Como resultado, nosso hipotético tema secundário permanece aberto e incompleto.

Para esclarecer, na teoria musical contemporânea, fala-se de uma cadência evadida [evaded cadence] sob as seguintes condições: (1) um processo temático está em andamento e promete um desfecho cadencial, geralmente por meio de uma progressão cadencial autêntica completa, com o arquétipo $I^{(6)}$-pré-dominante-V em posição fundamental-I em posição fundamental; (2) a dominante em posição fundamental será alcançada, mas a tônica cadencial será retida-evitada, negada, evadida; (3) frequentemente a evasão será sinalizada por uma condução melódica disjunta no soprano, no baixo ou em ambos, criando assim uma ruptura no processo de condução de vozes (ao invés de uma interrupção, em sua acepção schenkeriana); e (4) a música que se segue inicia estritamente um novo agrupamento com um começo distinto, em vez de uma elisão com um fim-início simultâneo. Simplificando, e como o termo sugere, a cadência evadida não é realmente uma cadência, pois a cadência não é articulada. As quatro condições estão em evidência nos compassos 22-23. Observe que o grau $\hat{7}$ na mão direita, Dó\#, não consegue resolver em $\hat{8}$, Ré, no mesmo registro, exigindo que o tecladista salte para a oitava superior; observe também que a harmonia se move enganosamente para um acorde de $\mathbf{v i}^{7}$.

Tendo seu início no compasso 23, uma verdadeira sequência por quintas descendentes, com hemíola, materializa a alusão anterior feita a essa sequência, com a voz superior compreendendo o espaço de uma sexta descendente até atingir a nota primária Fá\# no compasso 26. (Minhas anotações analíticas propõem que a nota primária foi fundamentalmente prolongada durante toda a exposição, como seria típico em exposições que modulam de i a III.) Uma escaramuça ao estilo de uma tocata, contribuindo adicionalmente para o "estilo misto" e com imitação entre as mãos esquerda e direita, ascende à nota primária em seu "registo obrigatório" no compasso 28; na sequência, o movimento descendente ( $\hat{3}-\hat{2}-\hat{1}$ na mediante) se completa com a cadência autêntica no compasso 29. Portanto, este "tema secundário" se torna bastante expandido,

\footnotetext{
${ }^{28}$ Me refiro aqui à noção de "interpretação formal retrospectiva", conforme elaborado em Schmalfeldt 2011, p. 9 e passim.
} 
MUSICA THEORICA Revista da Associação Brasileira de Teoria e Análise Musical 2020, v. 5, n. 1, p. 1-52 - Journal of the Brazilian Society for Music Theory and Analysis @ TeMA 2020 - ISSN 2525-5541

como é comum em formas de sonata posteriores a esta, nas quais, tradicionalmente, os materiais secundários são tratados de forma mais expansiva que os temas principais. A primeira metade da forma termina com uma ampla codeta de quatro compassos (c. 29-32), cujo movimento descendente carrega a música ao registro mais grave.

Agora, acontece que, como demonstrado no Ex. 3, o ponto crux, que marca o início da série de "compassos correspondentes" de Hepokoski e Darcy na segunda metade da forma, ocorre (no c. 47) exatamente onde o incomum prolongamento de permanência sobre a dominante começou na primeira metade. Todos os sete compassos de dominante retornam, agora sobre a dominante da tonalidade inicial, e lançam, desta vez, o feitiço hipnotizante de seu caráter sobre o movimento completo. O que se segue é um retorno quase idêntico do suposto "tema secundário" e sua codeta (que não constam no exemplo), todos agora transpostos para a tonalidade de Si menor. Independente do termo tema ser apropriado ou não, os materiais desta "zona-S" "obedecem às regras" da sonata Clássica, como diz Kirkpatrick, mas somente após a retomada da tônica inicial, e não durante a recapitulação do tema principal. ${ }^{29}$
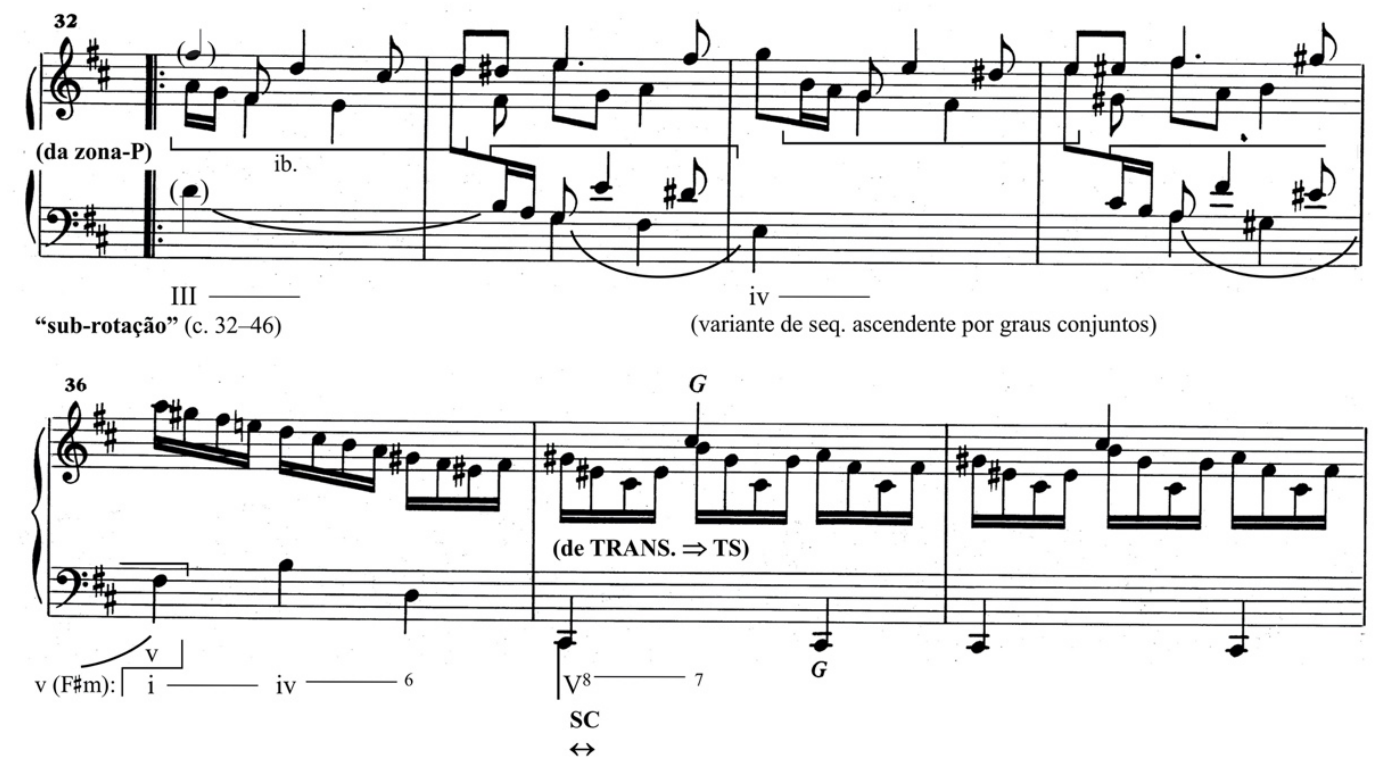

29 Para acessar as partituras completas das cinco sonatas discutidas neste artigo, vide a edição completa de Kenneth Gilbert (1971-1984). 

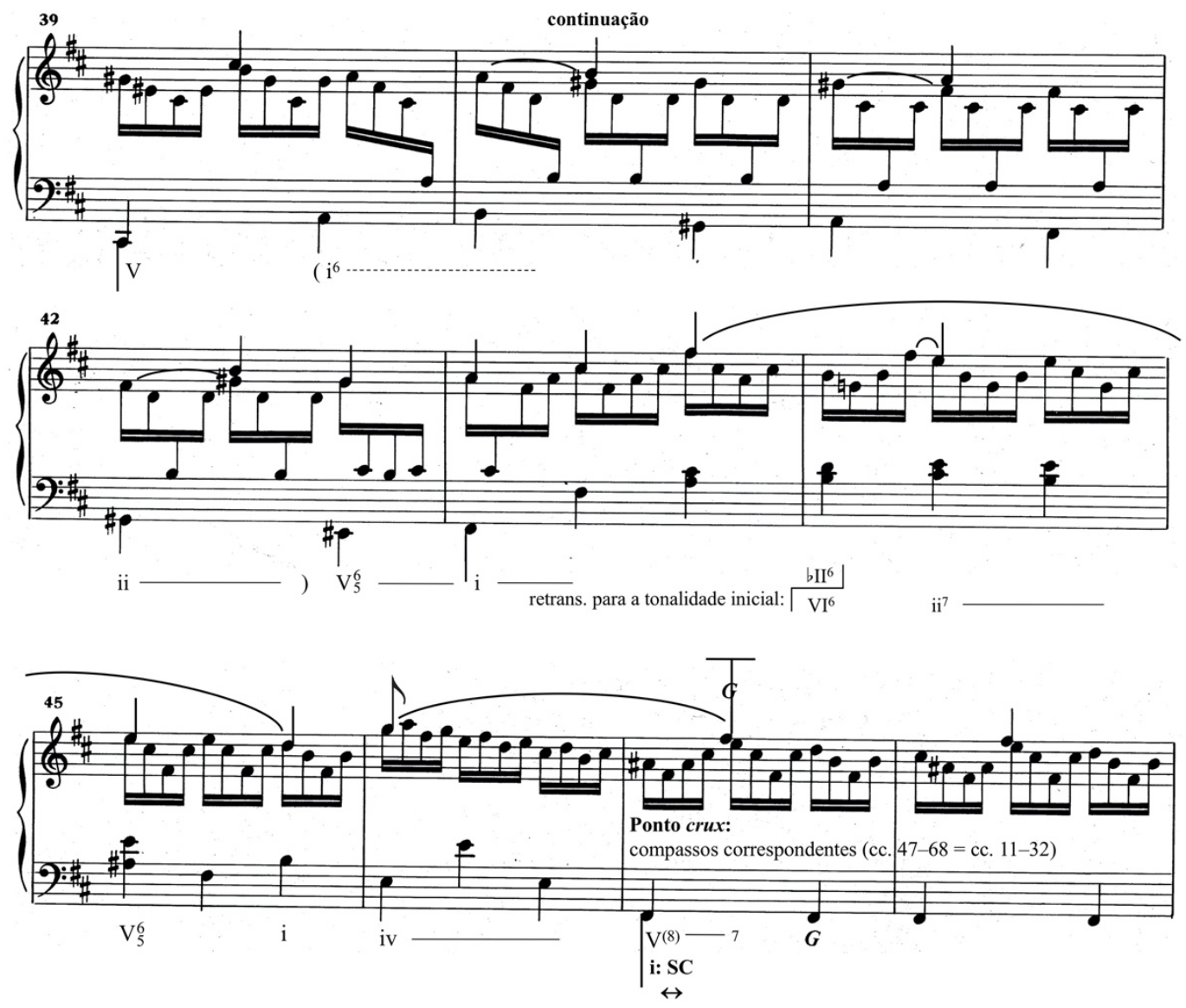

Exemplo 3: Scarlatti, K. 27, c. 32-48

Resta-nos examinar como Scarlatti abre a segunda metade - a "segunda rotação" - e atinge o ponto crux na dominante da tonalidade inicial. Hepokoski e Darcy propõem dois tipos característicos de inícios para a segunda metade em Scarlatti. O primeiro, e muito menos comum, seria começar com um retorno quase literal da abertura da obra, agora na tonalidade atingida ao fim da primeira metade, revertendo assim o movimento tonal tônica/não-tônica, realizado na primeira metade, ao longo da segunda; a este plano, os autores aplicam o termo "forma binária paralela" $(2006,355) \cdot{ }^{30}$ Scarlatti não pode utilizar esta opção aqui: sua primeira metade termina na mediante, e uma transposição literal da frase inicial de quatro compassos para essa tonalidade soaria, de fato, bastante incomum. Na verdade, em contraste com muitas sonatas Tipo 2 posteriores, escritas por outros compositores, nas quais a "forma binária paralela" pode ser

${ }^{30}$ Como exemplo de "forma binária paralela", os autores discutem a K. 2 de Scarlatti, em Sol maior. 
frequentemente encontrada, a tendência de Scarlatti é abrir a segunda metade com o que verdadeiramente pode ser chamado de "espaço de desenvolvimento". Aqui, sua segunda metade começa na mediante com a ideia básica original, mas a ideia é então "desenvolvida" como parte de uma variante elaborada de uma sequência ascendente por graus conjuntos (ou por segundas) (uma série de quintas e sextas ascendentes, aqui quintas e décimas); atingindo, no compasso 37, a dominante da dominante menor, Fá\# menor. Agora, tanto o prolongamento de permanência sobre a dominante (TR) quanto a frase de continuação de seu tema secundário (S) retornam aqui sobre o quinto grau menor (v). Desta vez, o "prolongamento de permanência" equivale apenas a uma unidade de três compassos (c. 37-39), e a continuação do tema secundário se funde com a modulação necessária para o retorno à tonalidade inicial nos compassos 44-47. Assim, dizer que toda a segunda metade da K. 27 consiste simplesmente em uma "segunda rotação" é não contar a história toda: o "espaço de desenvolvimento" possui sua própria "sub-rotação" - de materiais de P, TR, e S nessa ordem - e, portanto, é comparável à segunda das três rotações que constituem uma típica sonata Tipo 3, aquela dedicada ao desenvolvimento. O que se segue consiste, como mencionado, em outra excursão por TR + S, desta vez "recapitulando" esses materiais na tonalidade inicial.

\section{K. 519 e o estilo "espanhol"}

Sutcliffe descreve a Sonata K. 27 de Scarlatti como "um diálogo entre o estilo culto e o estilo de tocata", sendo o último remanescente das tocatas do pai de Domenico. ${ }^{31}$ Este é, portanto, o caso de um "estilo misto" no qual, durante a segunda parte de cada metade, ambos os estilos passam a "tomar emprestado, na verdade, aprender um com o outro" (2003, p. 153 e 155). Para um exemplo contrastante, refiro-me a uma obra que pelo menos um scarlattiano considera claramente "espanhola" - sua Sonata em Fá menor, K. 519, cuja primeira metade é ilustrada no Ex. 4a. A cravista e estudiosa Jane Clark (2000, p. [5]) considera esta obra como "uma das mais andaluzas de todas as sonatas", portanto não "mista". Principalmente notáveis são os longos trechos de textura homogênea, o ritmo incansável de colcheias, e o que Clark ouve como a ilusão de palmas, zapateado e

\footnotetext{
${ }^{31}$ Sutcliffe reconhece que nenhum dos termos que ele utiliza - culto e tocata - "é ideal, mas ajudam a capturar a oposição clara dos tipos sintáticos" (2003, p. 153).
} 
um melisma vocal ao redor de uma nota. Observe também que a primeira metade, bem como a segunda, termina com chamadas de trompa no modo maior. 32

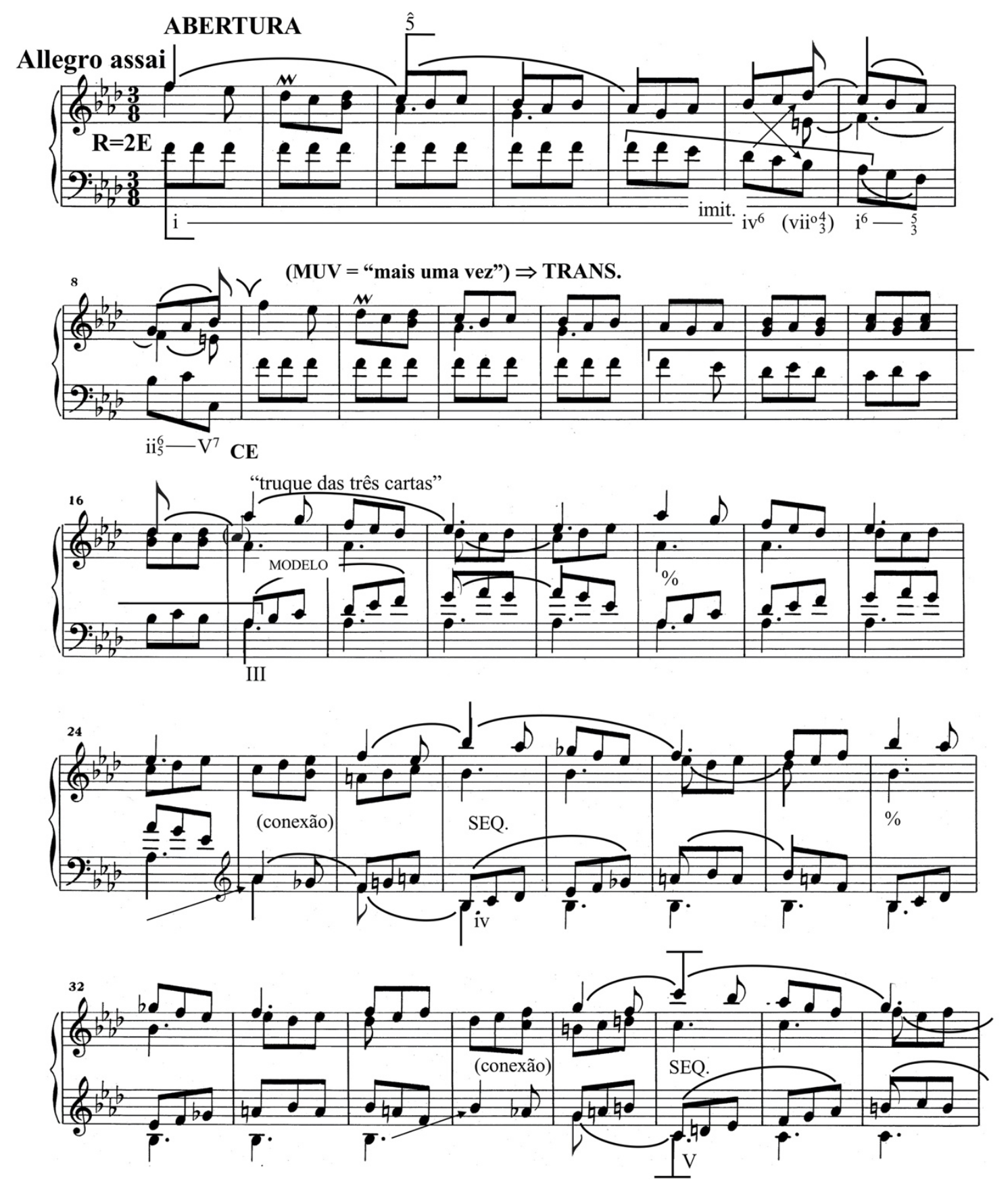

32 Em comunicação pessoal, Sutcliffe propôs que seria tão apropriado quanto perceber a K. 519 como uma "tarantela italiana". A introdução das chamadas de trompa-uma nova "tópica" - vai contra a ideia de um estilo andaluz puro, "não misto". 

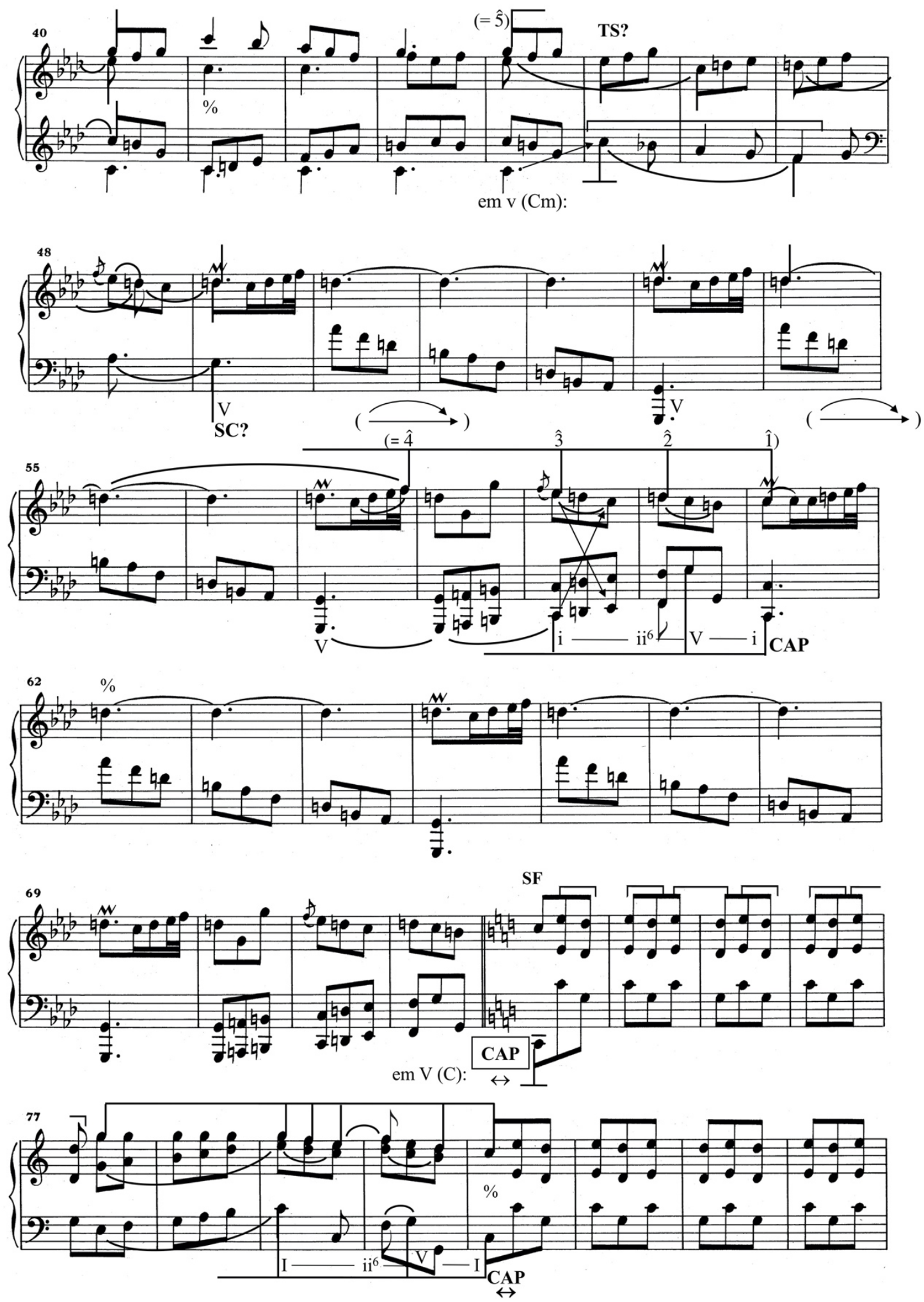


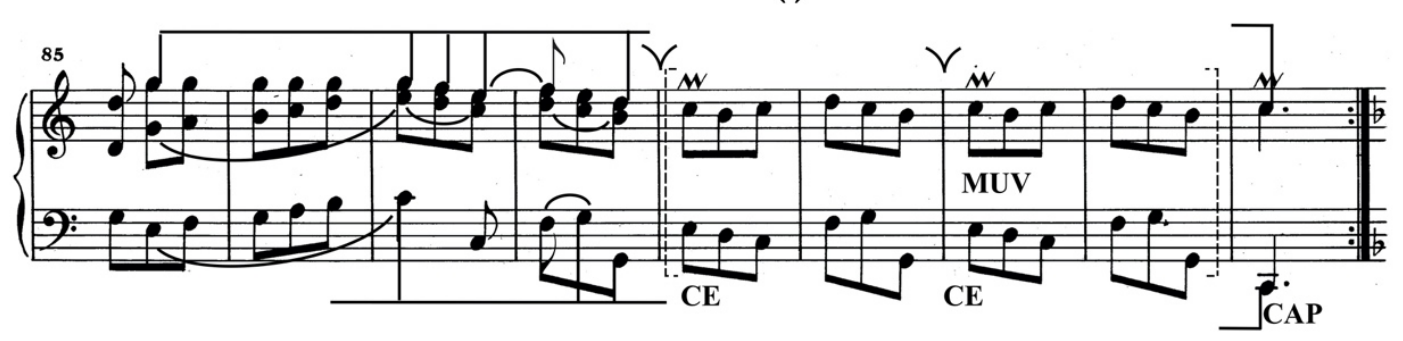

Exemplo 4a: Scarlatti, Sonata em Fá menor, K. 519, c. 1-93

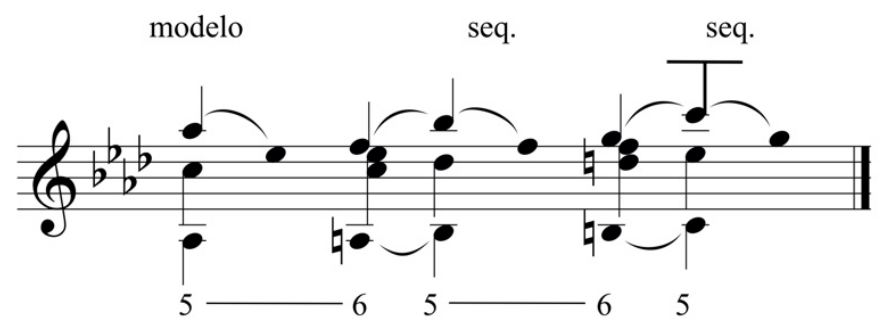

Exemplo 4b: Scarlatti, Sonata em Fá menor, K. 519, redução dos c. 17-44: sequência ascendente por graus conjuntos

Deveria ser evidente, a partir de minhas anotações analíticas, que o esforço resultante da comparação desta exposição com processos associados a formas de sonata posteriores produz resultados duvidosos. Dada a indicação de andamento, Allegro assai, a frase de abertura, escrita em oito compassos, provavelmente será percebida como uma única unidade vibrante de quatro compassos ( $\mathrm{R}=2 \mathrm{E}$ : um compasso "real" equivale a dois compassos escritos). Como na K. 27, uma imitação pode ser percebida: o movimento descendente por graus conjuntos a partir de 1 na voz superior, compassos $1-5$, retorna no baixo com uma pequena diminuição nos compassos 5-7. Aqui, entretanto, não haverá uma articulação cadencial típica de um tema principal. Uma cadência evadida no compasso 8 ativa a repetição da frase "de quatro compassos", e seu final é novamente não cadencial; uma modulação para a mediante (III: Láb maior) sugere que a transição já está em curso.

O trecho seguinte exibe um dos dispositivos favoritos de Scarlatti, o qual Sutcliffe denominou como o "truque das três cartas": ele o define como uma "sequência de três partes que envolve a transposição completa [ou variada]" de uma frase, "geralmente em movimento ascendente" e "muitas vezes dramatizado pelo uso do silêncio ao redor de cada uma das unidades (2003, p. 
MUSICA THEORICA Revista da Associação Brasileira de Teoria e Análise Musical 2020,

v. 5, n. 1, p. 1-52 - Journal of the Brazilian Society for Music Theory

140-41). ${ }^{33} \mathrm{O}$ nome não poderia ser melhor: Scarlatti, o trapaceiro, talvez até o jogador, o vigarista, que blefa e escapa, tendo ganho a mão! A frase dos compassos 17-24, realizada sobre um pedal de mediante, mas extraída da abertura da obra, encontra uma breve conexão (nos c. 25-26) que eleva sequencialmente este modelo em um tom, movendo-o à subdominante (iv). Estes dois "truques" produzem o terceiro, outra sequência ascendente (nos compassos 27-37) que nos conduz agora à dominante menor (v). Dentre as seis categorias de sequências harmônicas apresentadas por Caplin, este padrão harmônico constitui, portanto, uma variante da sequência ascendente por graus conjuntos (por quintas e sextas ascendentes), como ilustrado na redução do Ex. 4b. ${ }^{34}$

Até aqui não houve qualquer interrupção textural, portanto, nenhuma cesura medial para sugerir o fim de uma transição. Ao invés disso, a última sequência avança para um novo material melódico no compasso 45, com uma

${ }^{3}$ Sutcliffe introduz a expressão "truque das três cartas" em referência à Sonata de Scarlatti em Sol menor, K. 476 (na segunda metade, c. 96-110), na qual o procedimento invoca uma "influência ibérica". Ele interpreta o "truque", na K. 519, como um "dispositivo natural, mas pouco artístico, para intensificação"; aqui, ele carrega "referências populares" e, por poder ser encontrado nas obras para teclado de Durante e Marcello, sugere "uma sintaxe particularmente italiana" (2003, p. 181). Dos três trechos de Domenico Scarlatti discutidos por Gjerdingen (2007), dois - exemplos do esquema "Monte" para Gjerdingen - são exemplos do "truque das três cartas" (vide 2007, Exs. 7.9 e 7.10, p. 96-97). Gjerdingen também apresenta exemplos de "Montes em três partes" de Riepel (Ex. 7.5), Clementi (Exs. 7.6 e 7.7) e Fenaroli (Ex. 7.11). Seus exemplos do Monte Romanesca (de Fenaroli, C.P. E. Bach, Durante, Quantz, Mozart e Tritto) combinam estranhamente a direção ascendente do Monte com o movimento de terças descendentes da Romanesca.

34 Vide Caplin (1998, p. 29-31). De Caplin (2013, p. 20): Progressões sequenciais envolvem harmonias organizadas de acordo com um padrão interválico consistente entre suas fundamentais. [. . .] existem seis padrões de movimentação entre fundamentais disponíveis para sequências: movimento ascendente e descendente por quintas, terças ou segundas. (O movimento entre fundamentais por quartas, sextas e sétimas é logicamente acomodado em uma das seis categorias por inversão.)" As muitas sequências partimentistas e "os movimentos diatônicos por graus conjuntos" que fazem uso de sequências exibidos por Sanguinetti (2012, p. 136-157) reforçam a notável variedade de caracteres que as categorias básicas de Caplin sustentam na improvisação partimentista. Cada uma das sequências praticadas no partimento pode ser identificada como uma rica variante de uma das seis categorias básicas de Caplin. Por exemplo, as sequências ascendentes por "5-6", "8 7-6" e "10 9-8", as que "ascendem por terças e descendem por graus conjuntos", e as que "ascendem por quartas e descendem por terças", todas se enquadram na classe básica da "sequência ascendente por graus conjuntos"; as que "descendem por quartas e ascendem por graus conjuntos" são exemplos da "sequência por terças descendentes". O "truque das três cartas" de Scarlatti ilustra uma complexa elaboração da sequência ascendente por graus conjuntos que não seria representada nos esquemas partimentistas mais simples relativos à movimentação do baixo. 
frase que se inicia na tônica, Dó menor (v), agora a tonalidade secundária. Este poderia ser o início de um "tema secundário", ou, ao menos, de uma "zona S"? Na segunda metade da obra, o ponto crux começará de fato com "compassos correspondentes" que têm início exatamente aqui. Mas os cravistas parecem ter dificuldade de marcar o compasso 45 como um novo início temático; pelo menos nas gravações que ouvi, nenhum deles tentou fazer isso, embora, em um instrumento moderno, um sforzando na nota Dó do tempo forte seria suficiente. No compasso 49, chegamos à dominante da nova tonalidade, com o início potencial de uma série de agrupamentos de quatro compassos (com $2 \mathrm{R}=4 \mathrm{E}$ ), conforme indicado na partitura. A dominante do compasso 49 pode servir como o objetivo final de uma progressão semi-cadencial que pontua o fim de uma transição? Clark certamente a interpreta como tal; ela, de fato, faz uma pausa antes de prosseguir. Mas sua performance também sugere um "prolongamento de permanência sobre a dominante"; ela adiciona floreios melismáticos maravilhosamente selvagens à nota aguda (Réł) sobre os arpejos das tétrades diminutas de função bordadura, pausando a cada vez sobre o acorde de dominante, até que, finalmente, uma ideia cadencial bastante curta conduz à cadência autêntica perfeita (CAP) no compasso 61. A passagem que tem início no compasso 50 é então repetida, sugerindo a função de um "tema secundário", tema este bastante diferente dos tipos Clássicos posteriores.

Por outro lado, a elisão cadencial do compasso 73 introduz o que inequivocamente pode ser chamada de uma seção de fechamento distinta, anunciada por sua triunfante modulação para a dominante maior e por suas chamadas de trompa, como se, na imaginação de Kirkpatrick, "elas tivessem acabado de ser ouvidas pelas janelas do palácio" na residência do compositor ([1953] 1983, p. 201). Com uma hemíola irresistível, a primeira frase termina com uma cadência autêntica no compasso 81, com elisão. Durante sua repetição, o "mecanismo de escape" mais característico de Scarlatti se revela: uma cadência evadida (CE) no compasso 87 motiva o que se tornou coloquialmente conhecido, graças a mim, como uma repetição "mais uma vez" (vide Schmalfeldt 1992). A tônica em primeira inversão, e não em posição fundamental, ocupa a cabeça do compasso 89, impedindo assim a articulação cadencial. Essa evasão serve como convite para um segundo esforço, mas a tônica cadencial é novamente evitada. $\mathrm{O}$ compositor então "retorna", repetindo o esforço cadencial "mais uma vez", e desta vez com sucesso: uma cadência autêntica é agora alcançada. No final da 
segunda metade da sonata (c. 165-166), mais uma "mais uma vez" (não consta no exemplo) atrasa a cadência final, celebrando-a com ainda mais satisfação.

O melhor acrônimo para a técnica "mais uma vez" talvez seja CE + MUV: defino a estratégia como aquela que emerge apenas quando um processo temático promete um desfecho cadencial, mas tem sua tônica final retida. $\mathrm{O}$ esquema, ou norma, contra o qual o efeito da CE + MUV pode ser medido é simplesmente, portanto, o processo temático encerrado por uma cadência, e aqui este tipo de processo é perfeitamente demonstrado quando a primeira frase da seção de fechamento termina com uma CAP com elisão no compasso 81. Foi argumentado, e amplamente aceito também, que uma repetição que siga uma cadência autêntica imperfeita (CAI) ou uma cadência deceptiva (CD) [ou de engano]-ambas agindo como objetivos sintáticos genuínos, embora menos fortes que a CAP - não constitui uma repetição "mais uma vez". Estes tipos de repetição são relativamente estáveis; eles não transmitem o efeito de ruptura, de uma respiração pega de surpresa, que a cadência evadida pode sinalizar para os ouvintes e, especialmente, para os intérpretes. Podemos avaliar as diferenças em vigor substituindo a suposta CAI pela CAP com elisão do compasso 81 escolhida pelo compositor; é claro que o grau de conclusão seria enfraquecido, mas não haveria um distúrbio comparável ao efeito de falta de ar típica das cadências evadidas e da repetição MUV que adiam o desfecho da exposição em quatro compassos completos.

Ofereço apenas algumas palavras sobre o início da segunda parte da $\mathrm{K}$. 519, ilustrada no Ex. 5. Do começo da segunda rotação ao ponto "crux" no compasso 121, a tópica exclusiva será as "palmas e o zapateado" do início da sonata, mas com este material sendo utilizado agora para formar uma sequência ascendente - a princípio por graus conjuntos e, portanto, fazendo alusão ao "truque das três cartas" da suposta transição. Uma característica marcante do trecho, indicada na partitura, é a completa imprevisibilidade das frases e suas repetições. Conforme indicado, ouço as unidades escritas (e talvez com elisões) como 4, 5, 3, 4, 4 e, finalmente, $7(4+3)$, mas, claro, cada uma representando a metade da duração escrita. 

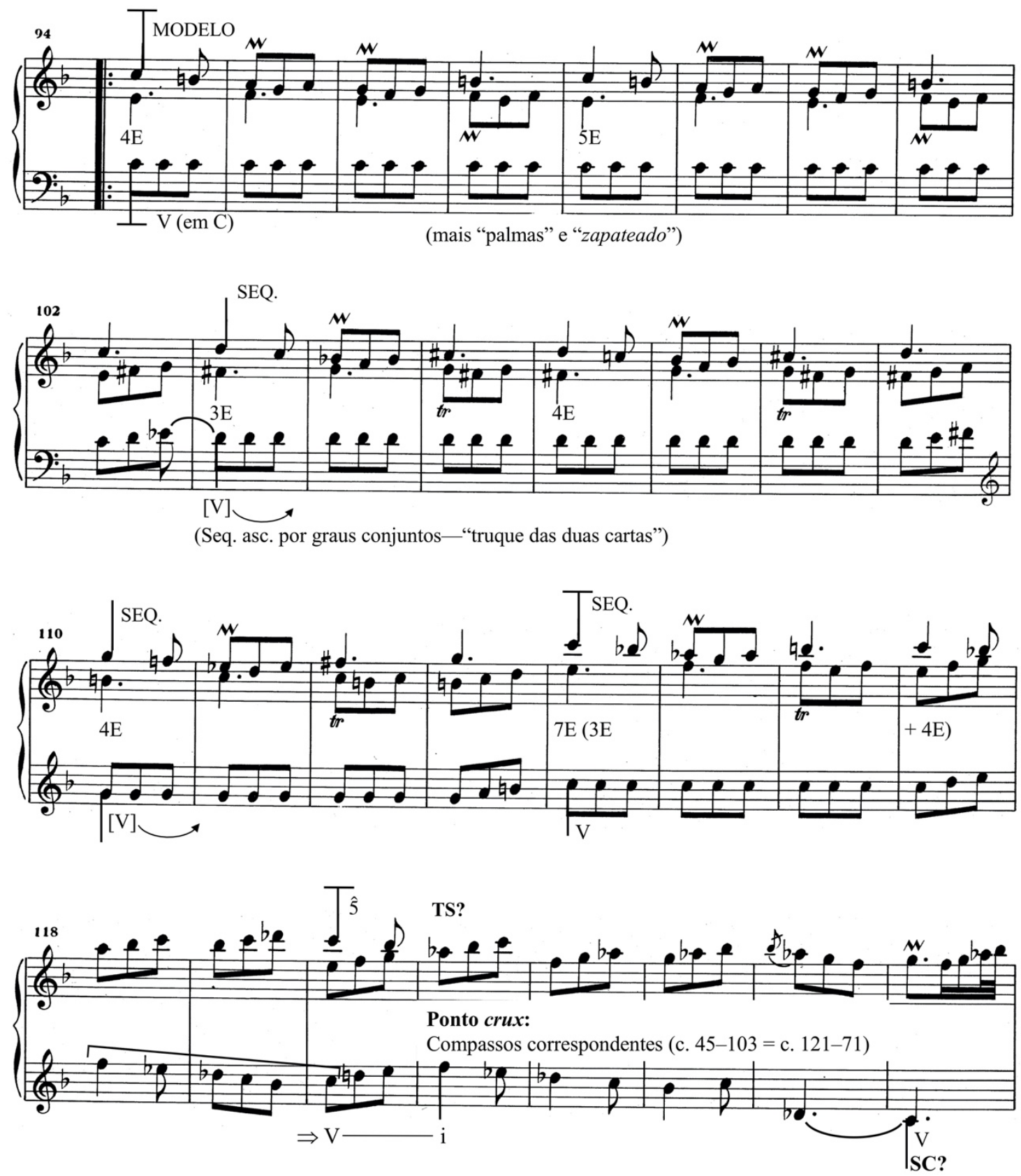

Exemplo 5: Scarlatti, K. 519, c. 94-125

\section{K. 159 e a "mais uma vez"}

Retratei deliberadamente a Sonata K. 519 de Scarlatti como uma obra que não se adapta bem à comparação com processos característicos da forma sonata do fim do século XVIII. No entanto, devo argumentar, sem restrições, que sua preferência excessiva pela cadência evadida e pela técnica "mais uma vez", como 
MUSICA THEORICA Revista da Associação Brasileira de Teoria e Análise Musical 2020, v. 5, n. 1, p. 1-52 - Journal of the Brazilian Society for Music Theory and Analysis @ TeMA 2020 - ISSN 2525-5541

pode ser visto nas seções de fechamento da K. 519, o coloca na companhia de inúmeros compositores de meados e fim do século XVIII, século XIX e muito além - até as produções de música e dança do vaudeville e do teatro musical da Broadway. ${ }^{35}$ Não estou sugerindo, de forma alguma, que compositores posteriores "aprenderam" a técnica com Domenico; com exceção do culto a Scarlatti na Inglaterra nas últimas décadas do século XVIII, a questão de quem, no continente, pode ter ouvido ou estudado algumas de suas sonatas antes dos primeiros anos do século XIX permanece aberta. ${ }^{36}$ Quero dizer apenas que a técnica "mais uma vez" se tornou amplamente difundida na ópera cômica e em muitos gêneros instrumentais no fim do século XVIII, especialmente como meio de expandir e revigorar temas secundários, e particularmente na música de Mozart. Pesquisadores dedicados ao estudo da relação entre a produção de Scarlatti para teclado e a música que o antecedeu poderão confirmar, acredito eu, que para nenhum compositor anterior a Scarlatti essa técnica havia se tornado uma marca estilística. Assim, a "visão" mais clara do estilo de Scarlatti na música do fim do século XVIII talvez seja constituída por evasões e adiamentos cadenciais quase previsíveis nas seções secundária e de fechamento. Outro exemplo, da exposição de sua Sonata em Dó maior, K. 159, é ilustrado no Ex. 6, com anotações.

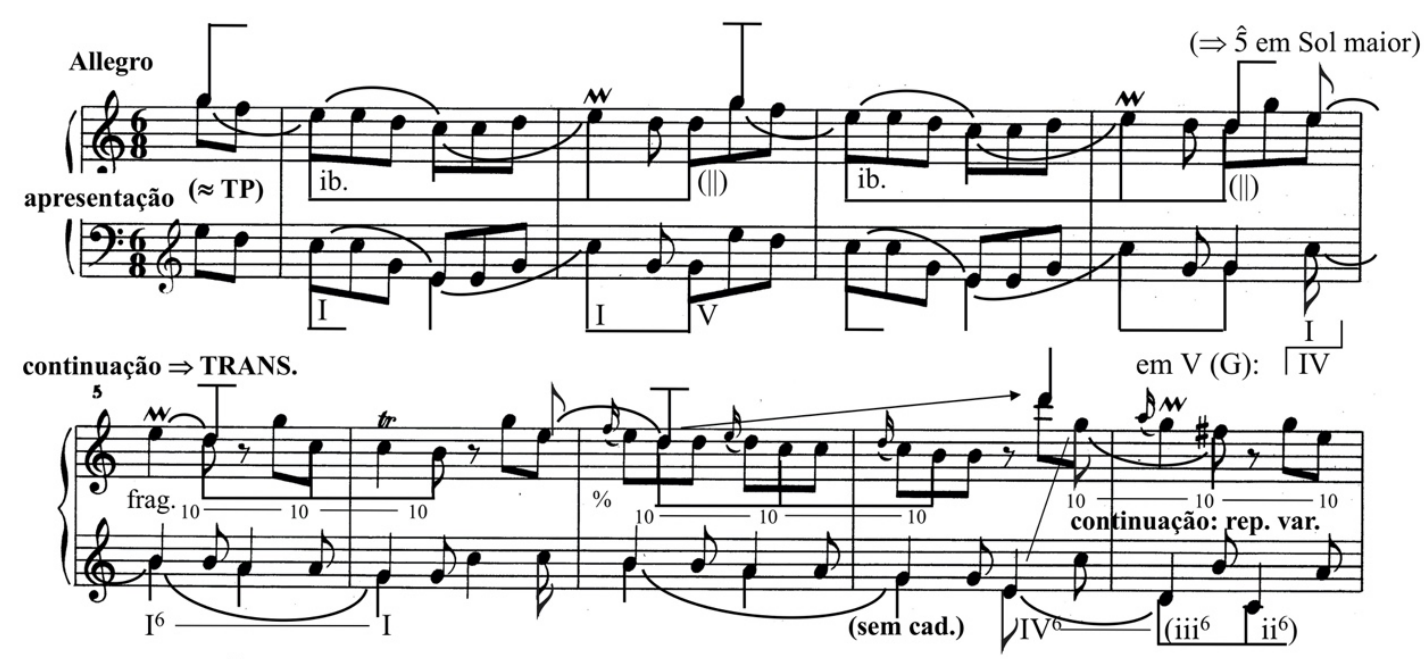

\footnotetext{
${ }^{35}$ Meu artigo sobre a convenção "uma vez mais" (Schmalfeldt 1992) apresenta exemplos de gêneros múltiplos de Scarlatti, Emanuel Bach, Mozart, Beethoven, Chopin, Verdi e Debussy, com referências a alguns compositores da Broadway.

36 Para uma visão geral da recepção da música de Scarlatti (e de sua ausência), vide Boyd (1987, cap. 10, "Scarlatti's Reputation and Influence", p. 205-223).
} 

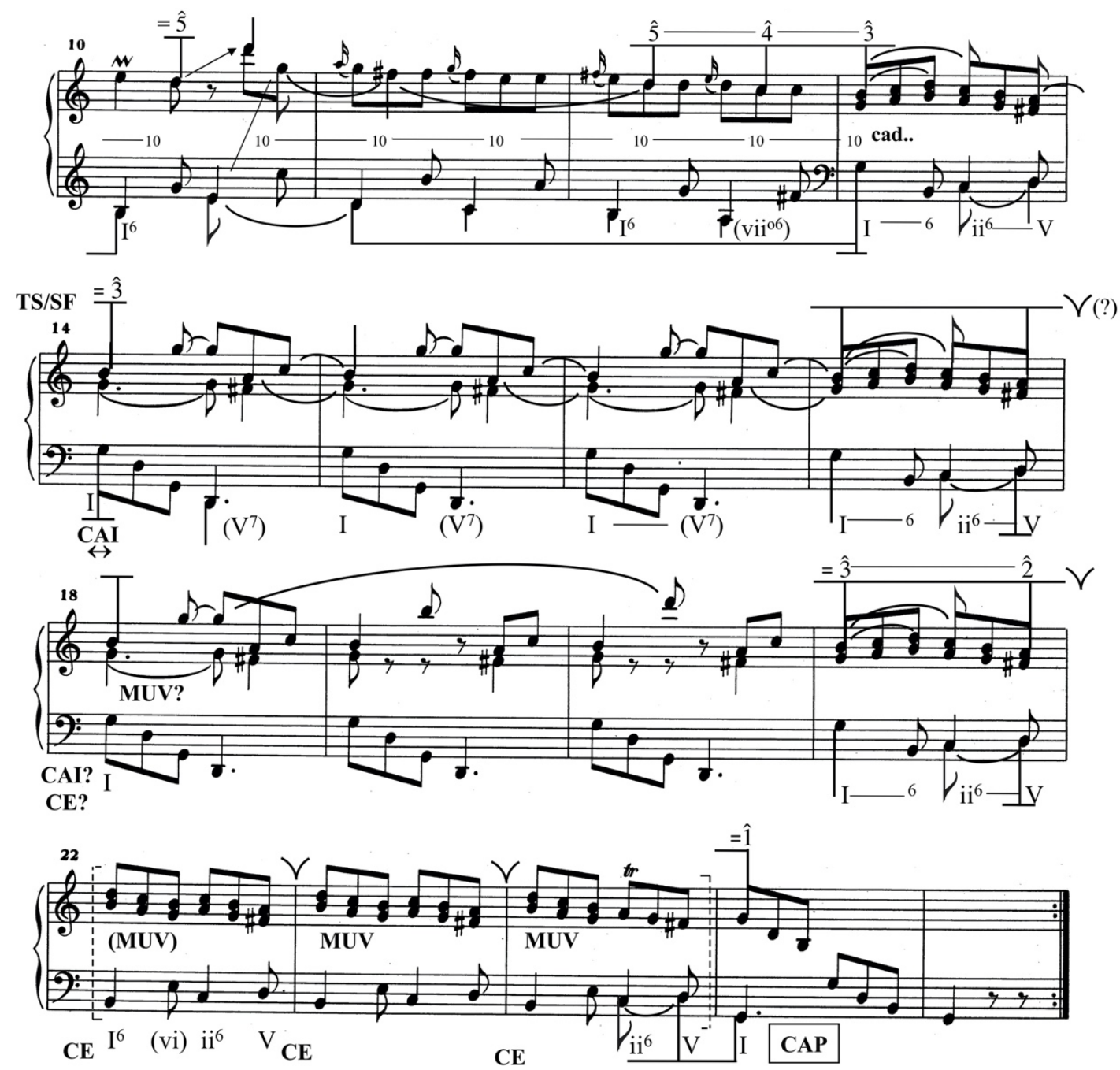

Exemplo 6: Scarlatti, Sonata em Dó maior, K. 159, c. 1-26

Permita-me enfatizar que nesta exposição a repetição imediata da ideia básica que inicia a obra - outra das fabulosas chamadas de trompa de Scarlattinão constitui uma repetição "mais uma vez". Não há cadências ou promessas destas nos compassos 1-4; um processo temático apenas foi iniciado. Ocupando a posição de um "tema principal", a ideia inicial de Scarlatti e sua repetição podem ser comparadas a uma apresentação de uma sentença Clássica de oito compassos. A fragmentação a seguir (c. 5-8) sugere uma continuação, com a exceção de que a frase não é concluída com uma cadência na tonalidade inicial; a ênfase sobre o acorde de dominante já sugere um movimento em direção à 
MUSICA THEORICA Revista da Associação Brasileira de Teoria e Análise Musical 2020, v. 5, n. 1, p. 1-52 - Journal of the Brazilian Society for Music Theory and Analysis@ TeMA 2020 - ISSN 2525-5541

dominante como tonalidade. ${ }^{37}$ Uma repetição variada da frase modula, inequivocamente, completando a transição para esta tonalidade secundária.

Acredito que só podemos reivindicar aqui a emergência de um tema secundário que serve a dupla função de tema de fechamento. A ideia cadencial do compasso 13 confirma a modulação, e o que parece ser uma cadência autêntica imperfeita com elisão (CAI) ocorre na cabeça do compasso 14 (a condução melódica $\hat{4}-\hat{3}$ no soprano se mantém no mesmo registro, não havendo, portanto, qualquer sensação de ruptura). Uma frase de quatro compassos se segue, com a mesma ideia cadencial retornando para predizer o desfecho. Mas, dependendo da forma como esta frase for interpretada [referindo-se aqui à performance], tanto outra CAI com elisão quanto outra cadência evadida podem ser comunicadas no compasso 18, neste último caso, resultando em uma repetição do tipo "mais uma vez". Sua própria cadência é inquestionavelmente evadida no compasso 22 e o que se segue são mais duas repetições do tipo "mais uma vez" da ideia cadencial. Em suma, esta exposição completa pode ser interpretada como um mini exercício de bravura sobre o adiamento do desfecho até que a cadência autêntica finalmente seja atingida no compasso 25 . Terei mais a dizer sobre esta sonata no fim do meu estudo.

\section{K. 481 e o motivo Láb}

É raro que compositores posteriores a Scarlatti empreguem a técnica "mais uma vez" no âmbito de um tema principal; a técnica tende a ser reservada para adiar o desfecho de temas secundários. O Ex. 7, do tema principal da Sonata para piano de Mozart em Dó maior, K. 309 (1777), oferece um caso bastante excepcional. Por outro lado, Scarlatti poderia lançar mão desta técnica a qualquer momento nas exposições e segundas partes de suas sonatas.

\footnotetext{
${ }^{37}$ Tanto Caplin quanto um leitor anônimo propuseram, independentemente, que a passagem dos compassos 5-8 da K. 159 de Scarlatti apresenta o que Gjerdingen chamou de "Prinner modulante" (2007, p. 58-59). Neste caso, conforme ilustrado no Ex. 6, o Mi do soprano, na anacruse do compasso 5, é reinterpretado como $\hat{6}$ em Sol maior e, passando pelos $\hat{5}$ e $\hat{4}$ graus, descende por graus conjuntos ao $\hat{3}$ no compasso 5 , sendo seguido pelo baixo em décimas; a ideia do "Prinner" recebe uma repetição ornamentada nos compassos $7-8$.
} 

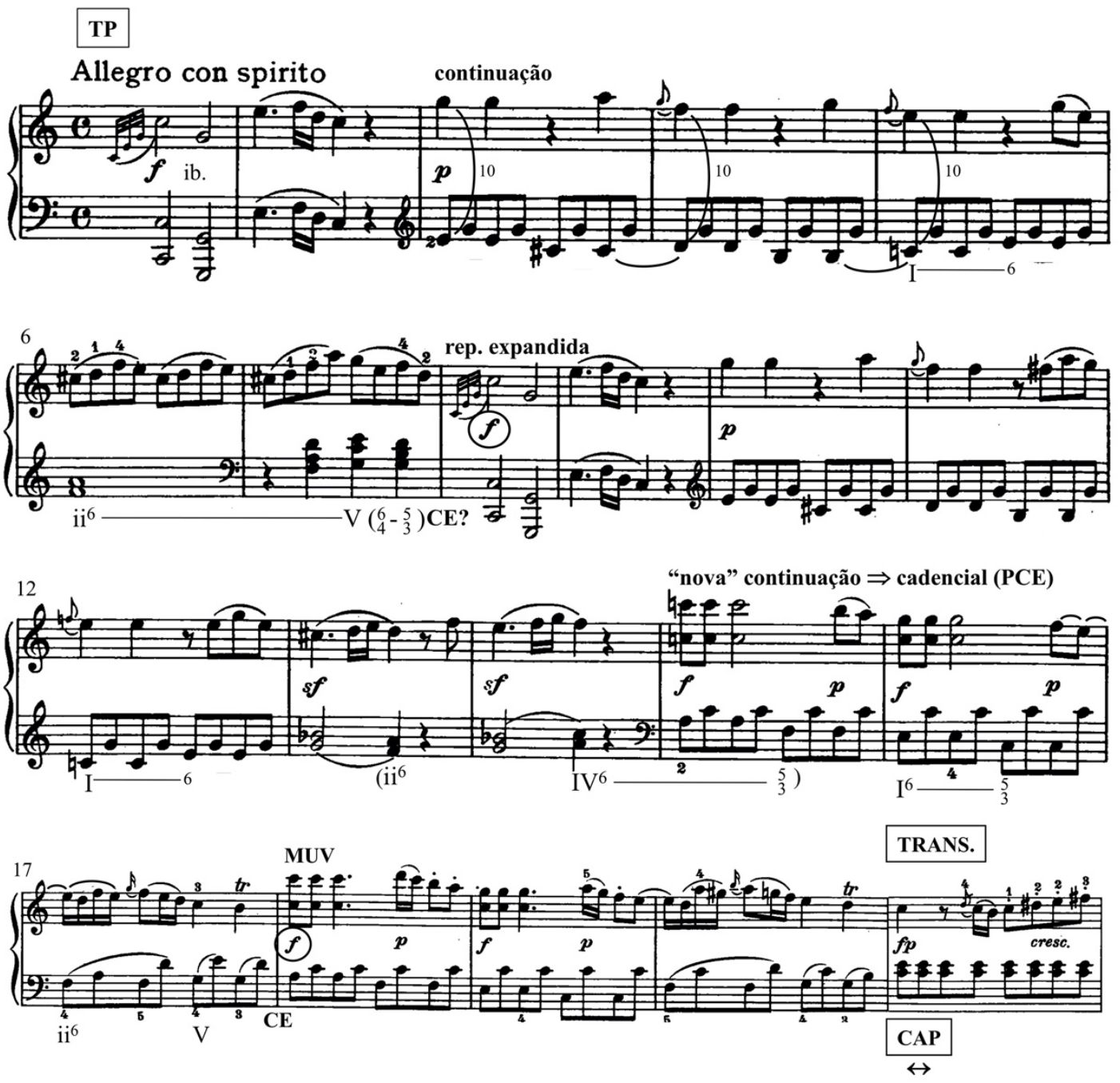

Exemplo 7: Mozart, Sonata em Dó maior, K. 309 (1777), c. 1-21

Relembre a cadência evadida ao final da primeira frase da Sonata em Fá menor, K. 519 (vide novamente o Ex. 4a): o movimento apressado que nos conduz à repetição imediata desta frase, que vem então a modular, pode muito bem ser executado como um caso da estratégia "mais uma vez"; de fato, exigindo saltos ascendentes em ambas as mãos ao atingir o compasso 9, a ruptura da condução melódica praticamente impõe o efeito de evasão. As diversas ocorrências da técnica "mais uma vez" nas seções secundária e de fechamento de sua Sonata em Fá menor, K. 481, contribuem bastante para a natureza austera, porém nostálgica, melancólica deste andante. Devo chamar a atenção para estes e outros aspectos 
MUSICA THEORICA Revista da Associação Brasileira de Teoria e Análise Musical 2020, v. 5, n. 1, p. 1-52 - Journal of the Brazilian Society for Music Theory and Analysis @ TeMA 2020 - ISSN 2525-5541

da sonata, com alguns excertos ilustrados nos Exs. 8a-d..$^{38}$ Aqui temos um caso em que um detalhe motívico distintivo e recorrente se torna inextricavelmente associado à estratégia CE + MUV.

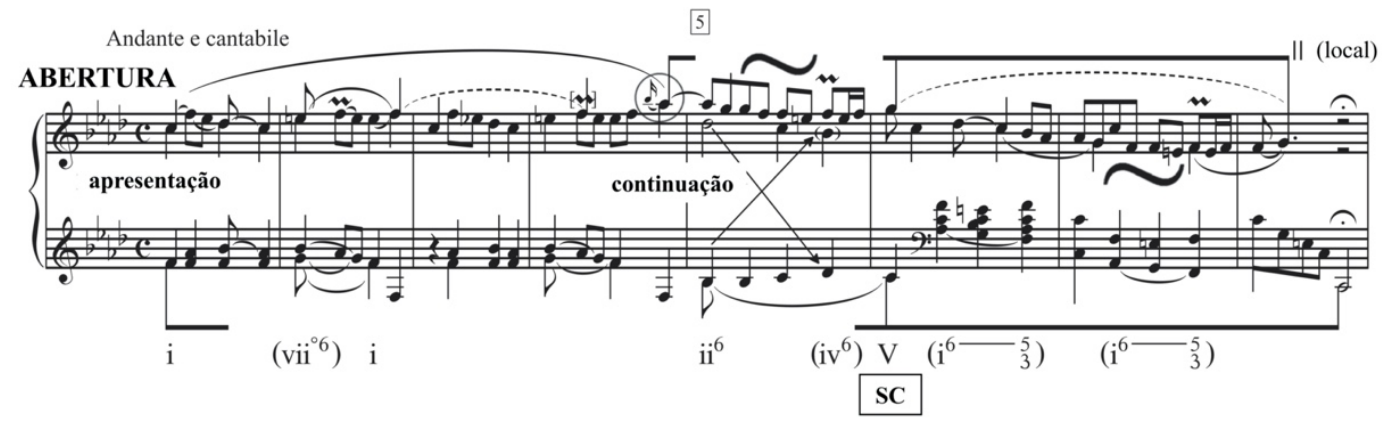

Exemplo 8a: Scarlatti, Sonata em Fá menor, K. 481, c. 1-8

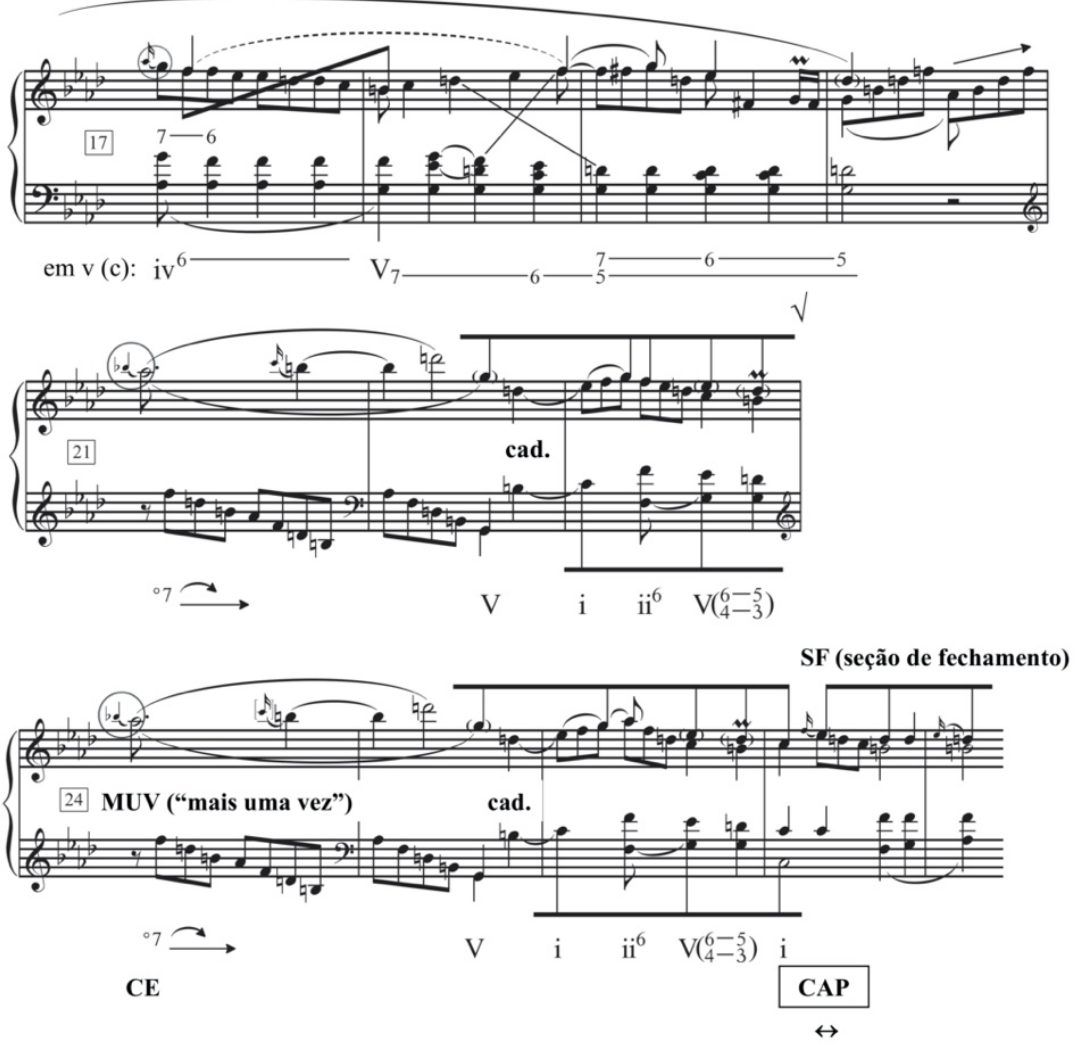

Exemplo 8b: Scarlatti, Sonata em Fá menor, K. 481, c. 17-28

\footnotetext{
${ }^{38}$ Agradeço a Peter C. W. Smucker, professor assistente de teoria musical da Escola de Música da Stetson University, Deland, FL, por transcrever os quatro trechos do Ex. 8 para o formato digital. O Ex. 2 deste artigo foi preparado por Etha Williams, uma estudante de graduação em musicologia na Harvard University a quem tenho grande respeito e sou profundamente grata.
} 
Como na Sonata em Dó maior, K. 159, a abertura desta peça (Ex. 8a) pode nos remeter à sentença Clássica de oito compassos: uma ideia básica inicial e sua repetição variada sugerem uma apresentação; a continuação, com o aumento da atividade rítmica e harmônica, conduz à dominante-uma semi-cadência aparente com fermata no compasso 8. "Aclássico", no entanto, ou pelo menos atípico, é que a dominante já foi prematuramente alcançada no compasso 6, sendo então prolongada enquanto soprano e baixo descendem para os registros médio e grave. Dando suporte a esta interpretação, minhas anotações analíticas propõem um arpejamento inicial que tem como destino o Láb agudo do fim do quarto compasso $-\hat{3}$ como nota primária - e em seguida uma interrupção local precoce (Unterbrechung) sobre $\hat{2}$. Um brilhante holofote reluz sobre este Láb, acentuado no débil quarto tempo do compasso, ligado ao próximo tempo, e ornamentado de forma tão pungente por uma apojatura. Ele pede para ser lembrado.

Uma transição se inicia sobre a mediante (Láb) no compasso 9, com um outro desenho sentencial. Na sua apresentação de quatro compassos (c. 9-12, não ilustrada), uma nova ideia introduz a figura da tercina, e sua repetição completa uma progressão cadencial expandida (PCE) que aqui assume a forma de uma "cadência auxiliar" em termos schenkerianos: $\mathrm{I}^{6}-\mathrm{ii}^{6}-\mathrm{V}^{7}-\mathrm{I}$ sobre a mediante. Mas esta não será a região tonal da zona secundária. A continuação, tendo início no compasso 13, assume a síncope como motor; um modelo e sua sequência por terças descendentes alcançam o objetivo, uma dominante com sétima na região da dominante menor (Dó menor) no compasso 18 (Ex. 8b). Observe, no compasso 17, o retorno do gesto de apojatura do compasso 4, aparecendo agora um tom abaixo (Láb-Sol, em vez de Si,b-Láb), mas talvez predizendo o que está por vir.

O prolongamento de permanência sobre a dominante nos compassos 1820 poderia haver marcado o fim de uma transição em estilos de sonata posteriores. Aqui, essa "tranca de dominante" [dominant lock] simplesmente não destranca [unlock]! Em vez disso, o movimento ascendente do compasso 20 resulta em uma transferência de registro que prepara o retorno literal do motivoapojatura em Láb, agora transformado harmonicamente pela tétrade diminuta de função bordadura na nova tonalidade, e reformulado como um ataque nervoso - 
MUSICA THEORICA Revista da Associação Brasileira de Teoria e Análise Musical 2020, v. 5, n. 1, p. 1-52 - Journal of the Brazilian Society for Music Theory and Analysis@ TeMA 2020 - ISSN 2525-5541

uma aparentemente inesperada, involuntária expressão de angústia. ${ }^{39}$ Como se para recuperar a compostura, a ideia cadencial do compasso 23 promete um fim, mas a cadência é evadida. A perturbação não pode ser contida: ouvimos o ataque "mais uma vez" até que a cadência autêntica do compasso 27, com elisão, traz alívio e resignação.

Tomando emprestado novamente a "terminologia da forma sonata", posso imaginar que Caplin consideraria o trecho completo dos compassos 9-27 como um exemplo de "Fusão entre a Transição e o Tema Subordinado" (1998, p. 203) - neste caso, como na K. 27, resultando em um tema subordinado que carece de uma função inicial (vide novamente n. 27). Na ausência de uma cesura medial, para Hepokoski e Darcy se revela, sem dúvida, uma "exposição contínua". Para mim, pode-se dizer que a transição "tornou-se" retrospectivamente o tema secundário (modulante). Independentemente da descrição escolhida, os esforços para a aplicação de uma terminologia desenvolvida para a análise de formas de sonata posteriores revelam tanto o surgimento de processos "Clássicos" na música de Scarlatti quanto o fato de tal terminologia ser inadequada para capturar o que faz com que passagens como esta sejam unicamente dele.

Com convicção, porém, podemos descrever o que se segue a partir do compasso 27 como uma seção de fechamento. Frases mais curtas de três compassos (não ilustradas) agora reforçam, de forma pós-cadencial, o desfecho autêntico ocorrido no compasso 27. Mas, a segunda destas frases, compassos 3032, novamente conduz a uma cadência evadida, ilustrada no Ex. 8c; e aqui, de novo, o motivo-apojatura de Scarlatti, sobre sua altura principal, Láb, se torna a raiz da ruptura. Outra vez reinterpretado harmonicamente (agora sobre o iv), o motivo não pode ser esquecido: outra repetição "mais uma vez" conduz este ponto à cadência. O tipo de transformação motívica testemunhada aqui é da mais alta ordem - sutil, engenhosa e com a técnica "mais uma vez" a seu serviço. Compositores posteriores a Scarlatti, cada vez mais inclinados à transformação e integração motívicas, provavelmente ficariam impressionados.

\footnotetext{
${ }^{39}$ Alguém pode se perguntar se Scarlatti "se lembrou" da K. 481 quando compôs a K. 519 (ou vice-versa, dependendo da cronologia desconhecida): ambas sonatas exibem em destaque um arpejo descendente de uma tétrade diminuta de função bordadura no baixo, demonstrando, ao mesmo tempo, como este gesto pode ser totalmente transformado pela força de andamentos contrastantes - lento versus rápido.
} 


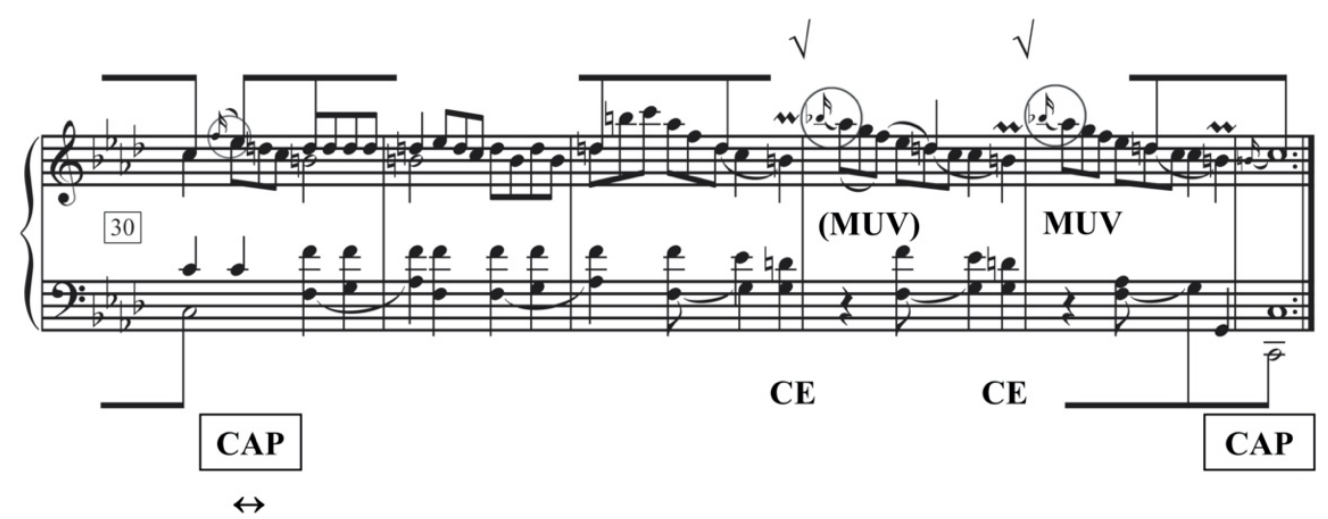

Exemplo 8c: Scarlatti, Sonata em Fá menor, K. 481, c. 30-35

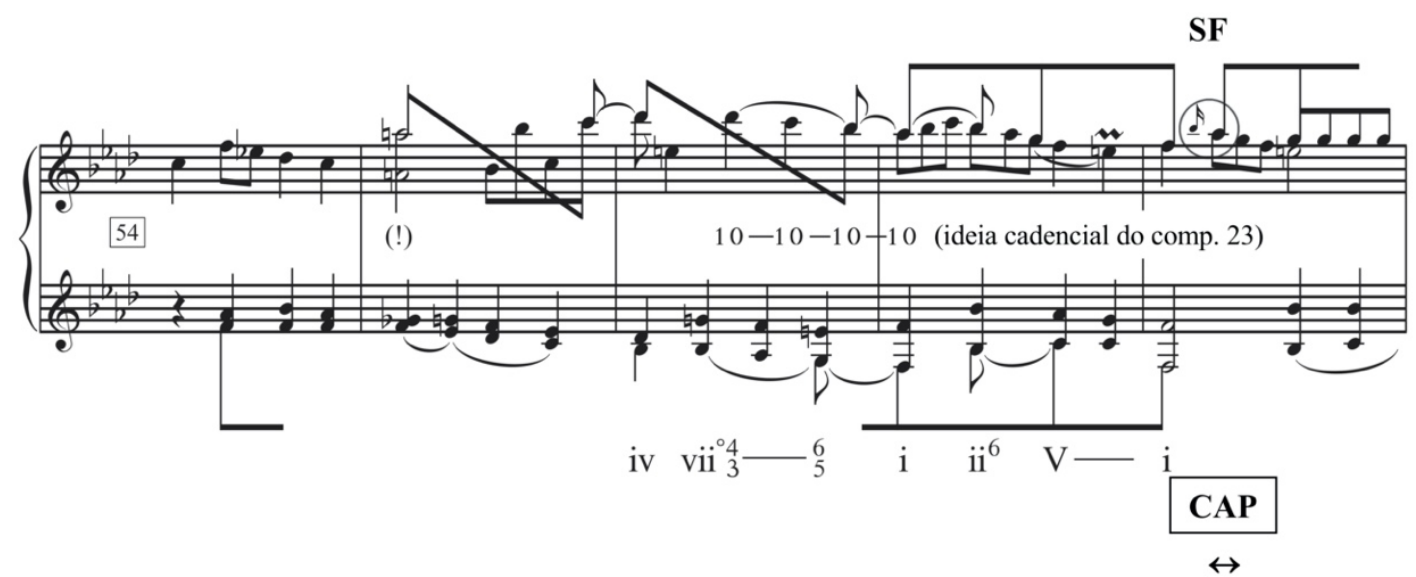

Exemplo 8d: Scarlatti, Sonata em Fá menor, K. 481, c. 54-58

No início da segunda metade da K. 481 (não ilustrado), a simples alteração de Mib para Mił transforma a tônica, Dó menor, na dominante da tonalidade inicial, estabelecendo um curto prolongamento da dominante, talvez comparável ao tipo de passagem que Joel Sheveloff denominou "vamp": nas palavras de Sutcliffe, uma daquelas "passagens aparentemente não temáticas e obsessivamente repetitivas que ocorrem com frequência nas sonatas". 40 Para Sheveloff e Sutcliffe, "vamps genuínos" geralmente se estendem por bem mais que meros quatro compassos; aqui, podemos dizer que temos apenas um "mini-

\footnotetext{
${ }^{40}$ Sutcliffe (2003, p. 23), parafraseando Sheveloff (1970, p. 364). Para sua própria, e mais detalhada, descrição de "vamp", vide Sheveloff (1980, p. 571); Sheveloff oferece um exemplo da K. 193 de Scarlatti. Ao menos um crítico já desprezou o termo vamp; vide Kroll (2004, p. 146).
} 
MUSICA THEORICA Revista da Associação Brasileira de Teoria e Análise Musical 2020, v. 5, n. 1, p. 1-52 - Journal of the Brazilian Society for Music Theory and Analysis@ TeMA 2020 - ISSN 2525-5541

vamp ${ }^{\prime 41}$ e, portanto, talvez o termo ocasional de Kirkpatrick - "flutuação" ${ }^{42}$ - seja mais apropriado. As tercinas nas duas vozes superiores, agora em diálogo imitativo, são obviamente "temáticas" - elas foram introduzidas na transição; as batidas dos acordes de função bordadura e sonoridade frígia imbuem o trecho com um caráter perturbado e reflexivo, mas não obsessivo. E, então, a meditação é rudemente interrompida.

Réb se torna, por enarmonia, Dó\# no compasso 40; aqui, um despertar é evocado pela entrada surpreendente do Láł, e uma progressão ascendente por grau conjunto, com $5^{\text {as }}$ paralelas, nada menos, leva abruptamente a harmonia para, dentre todas as regiões, a da dominante de Sol menor, a supertônica. Dos vários prolongamentos de dominante que esta peça exibiu, a "permanência" sobre uma dominante não ortodoxa como esta, nos compassos 41-44, expressa a maior urgência, e por uma boa razão: ela conduzirá a um retorno pleno e livre de variações dos três compassos iniciais da sonata-suficientemente raro para Scarlatti, e também na tonalidade "equivocada". Esta pode ser a única ocasião nas obras para teclado de Scarlatti que podemos falar daquilo que em um repertório posterior seria denominado "falsa reprise" - "falsa" porque ocorre na tonalidade improvável da supertônica e porque logo será seguida por aquilo que, a princípio, parece ser uma reprise "verdadeira". Como se a música soubesse que pegou o caminho errado, ela modula rapidamente para a tonalidade inicial e alcança sua tétrade de dominante (no c. 49), enfatizando-a novamente com outro "prolongamento de permanência" que termina, como antes, com uma pausa (mas agora sem fermata).

Com não apenas um, mas dois retornos do início da sonata, o segundo retornando à tonalidade inicial nos compassos 55-57, a segunda metade da $\mathrm{K}$. 481 não está mais em conformidade com o padrão temático ordenado característico de uma "segunda rotação". Analistas, em busca de traços de um tipo formal posterior, poderiam se sentir atraídos a comparar o segundo retorno

\footnotetext{
${ }^{41}$ Sutcliffe emprega o termo mini-vamp em referência aos compassos 46-53 da K. 402 de Scarlatti (2003, p. 129); para "o mais longo e, discutivelmente, mais extremo de todos os vamps de Scarlatti", ele se refere à K. 409 (p. 201).

${ }^{42}$ Por exemplo, de Kirkpatrick: "Características do amor de Scarlatti por flutuações [hovering] entre maior e menor são as progressões IV menor e V maior nas peças que imitam a música popular" ([1953] 1983, p. 210; grifo meu).
} 
com o início de uma recapitulação genuína, como parte de uma forma binária com recapitulação [rounded binary] ( I : A :| |: B A' :| |) ou mesmo de uma forma sonata Clássica do tipo 3. Nenhuma das comparações serão totalmente satisfatórias. A primeira metade da sonata, com suas zonas P, TR, S e F, se parece muito mais com uma exposição de forma sonata do que com a seção A de uma forma binária com recapitulação, tipicamente menos expansiva, mesmo quando esta seção apresenta uma modulação para uma tonalidade secundária; e a noção de que uma recapitulação completa de sonata pode estar em curso deve ser abandonada quando descobrimos que os materiais secundários da exposição não retornarão na tonalidade inicial. Com o choque impulsivo e completamente despreparado da dissonância no tempo forte do compasso 55, ilustrado no Ex. $8 \mathrm{~d}$, o compositor parece estar determinado a desafiar toda a expectativa de realização de uma forma que nos possa ser familiar - até mesmo a de Tipo 2. Ao invés de retornar ao seu motivo-apojatura sobre Láb do compasso 4, ele agora mira acima deste, no surpreendente Láł, e além. Somente a ideia cadencial (dos c. 23 e 26) permanece como vestígio dos materiais secundários de sua exposição; e então, no compasso 58, um desfecho autêntico definitivo é alcançado. Em resumo, houve apenas um "compasso correspondente" neste trecho.

Somente a seção de fechamento da exposição retorna agora. Conforme ilustrado no Ex. 8d, o motivo-apojatura sobre Láb reaparece imediatamente no compasso 58, recuperando seu suporte harmônico original (de tônica). Como nota primária e motivo central do movimento, Láb agora confirma o movimento descendente da Urlinie de $\hat{3}$ a $\hat{1}$, já fundamentalmente concluída nos compassos 57-58. As duas últimas cadências evadidas do final do movimento (c. 64 e 65), cada uma delas substituindo a tônica por um VI deceptivo, resumem o papel proeminente da estratégia "mais uma vez" nesta peça, enquanto oferecem ao desfecho da obra um descenso sombrio ao seu registro mais grave.

\section{K. 427, os "tiros de canhão" e virtuosismo com sequências}

A audácia das seções secundária e de fechamento de Scarlatti já foi notada há algum tempo, mas o papel persistente da cadência evadida e da estratégia "mais uma vez" tem sido negligenciado, assim como suas implicações para a performance. A técnica em si envolve um paradoxo: ela gera o efeito de fuga de um desfecho enquanto, ao mesmo tempo, enfatiza sua necessidade. Para 
MUSICA THEORICA Revista da Associação Brasileira de Teoria e Análise Musical 2020, v. 5, n. 1, p. 1-52 - Journal of the Brazilian Society for Music Theory

Scarlatti, o mágico, a estratégia "mais uma vez" pode assumir uma variedade infinita de caracteres-imprudentes e alegres, como nas chamadas de trompa de sua K. 519; provocativo e comemorativo, como em sua K. 159; inquietante e saudoso, como na K. 481. Esses papéis contrastantes apenas começam a descrever o alcance expressivo da técnica nas mãos de Scarlatti. Para um exemplo adicional, recorro a um dos casos mais radicais que encontrei, além de destacar o controle do compositor ao lidar com quase todas as categorias básicas de sequência harmônica comumente empregadas por compositores de sua era e de eras seguintes.

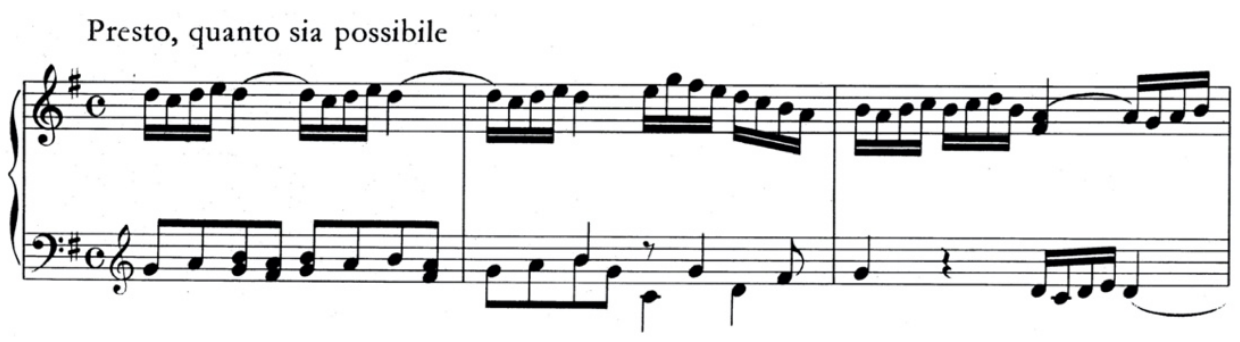

Exemplo 9a: Scarlatti, Sonata em Sol maior, K. 427, c. 1-3
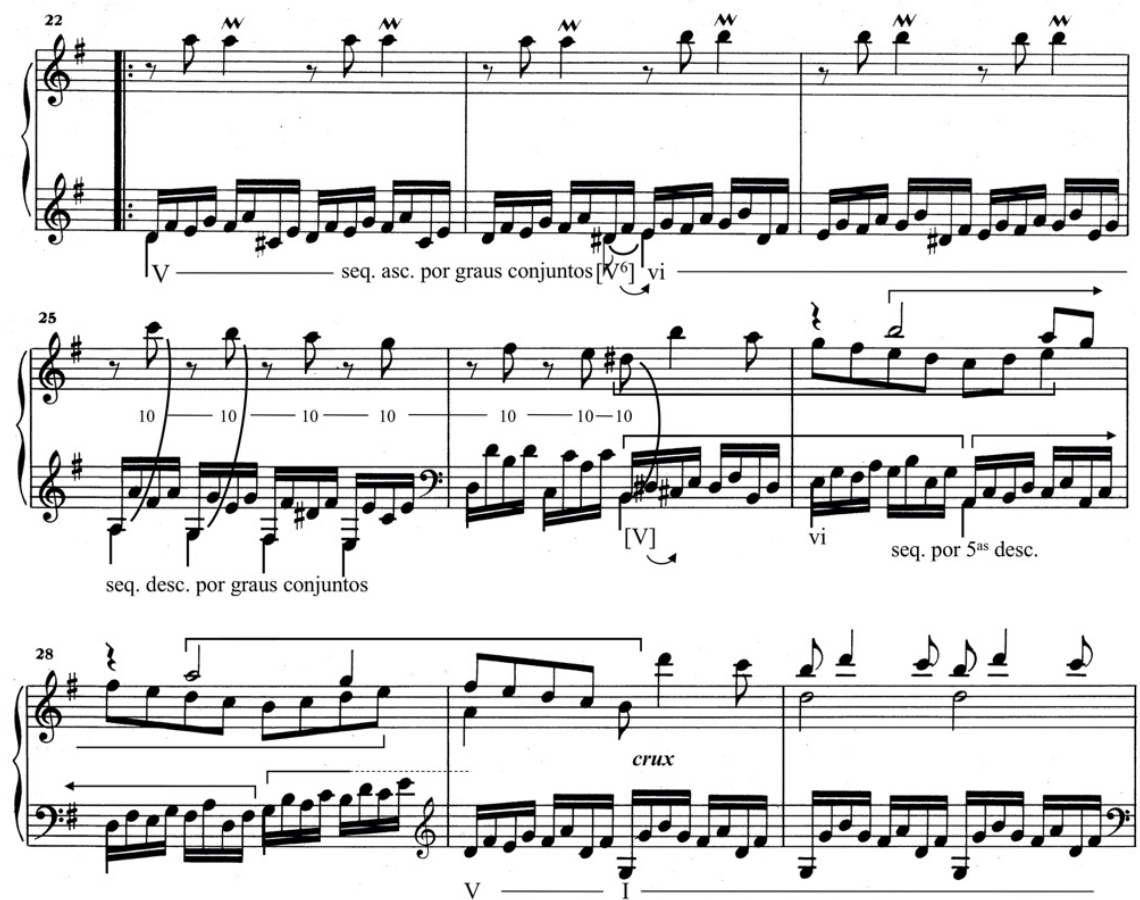

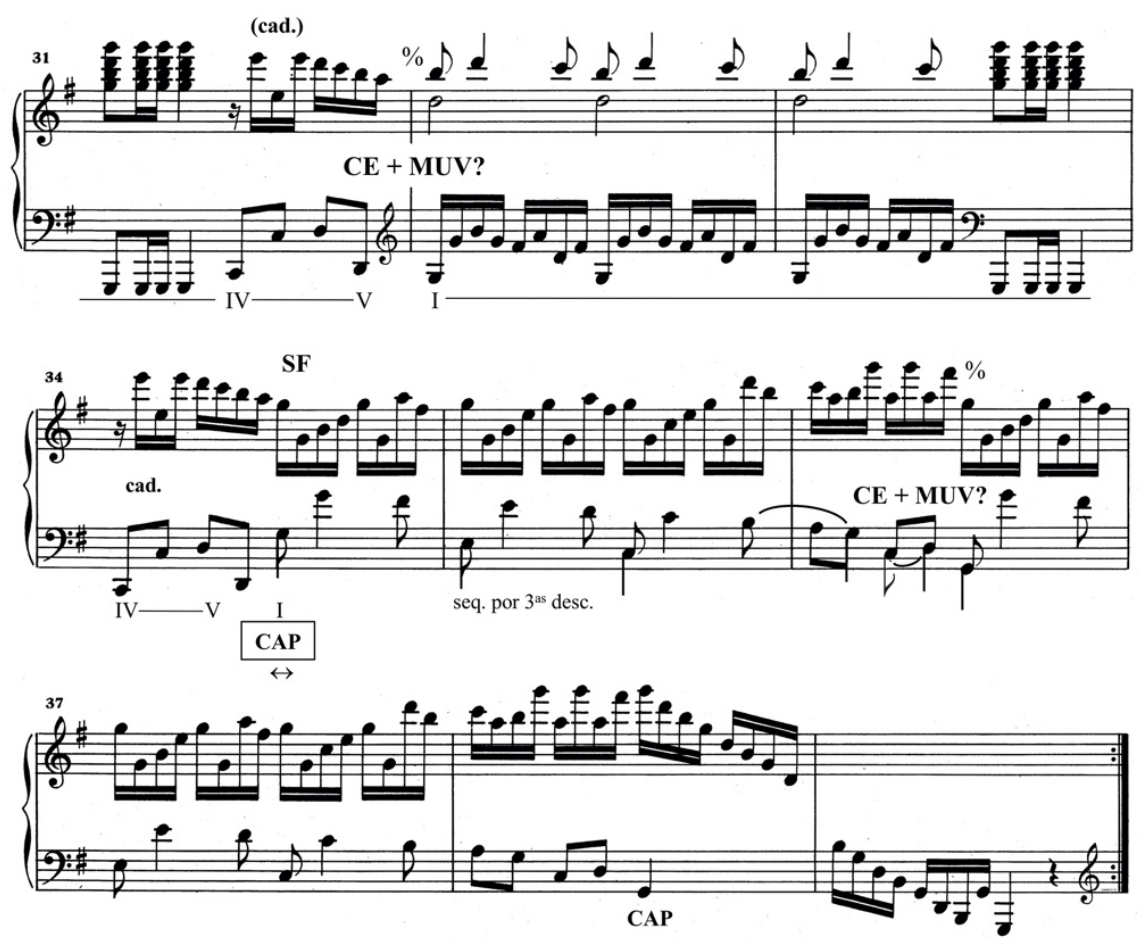

Exemplo 9b: Scarlatti, Sonata em Sol maior, K. 427, c. 22-39

O Ex. 9a mostra apenas o início da famosa Sonata em Sol maior, K. 427, para relembrar os leitores de seu andamento vertiginoso-Presto, quanto sia possibile. No Ex. 9b, vemos a acelerada segunda metade desta sonata, ao estilo de um Fortspinnung, que começa com um "trava-dedo" na mão esquerda derivado da transição (c. 10), ao invés de fazer referência aos materiais de abertura. ${ }^{43}$ Uma sequência ascendente por graus conjuntos-certamente uma das favoritas do compositor -e, em seguida, uma sequência descendente por graus conjuntos, movendo-se na direção oposta, conduzem à dominante de Mi menor (vi) no compasso 26, agindo como um ponto de chegada. Agora, outra sequência, desta vez por quintas descendentes, oferece ao intérprete um desafio indecente: conforme demonstrado pelos colchetes no Ex. 9b, o padrão sequencial da mão direita parece fora de fase com o padrão da mão esquerda. Um desafio maior está ainda por vir. A tônica inicial é atingida na metade do compasso 29, no ponto

\footnotetext{
${ }^{43}$ Sutcliffe considera a "acelerada segunda metade" da K. 427 e de outras sonatas como uma "característica formal". "A segunda metade, portanto, não é mais um tipo de rima da primeiraembora seja comum uma extensa transposição, já que contribui para a impressão de que nada pode impedir o impulso crescente-do que uma continuação e intensificação direta desta" (2003, p. 342).
} 
MUSICA THEORICA Revista da Associação Brasileira de Teoria e Análise Musical 2020, v. 5, n. 1, p. 1-52 - Journal of the Brazilian Society for Music Theory

crux relativo à exposição. Com suas síncopes exuberantes, este material secundário segue saltitando até que, de repente, somos golpeados, como na primeira parte (c. 13), por uma explosão altamente ruidosa-a "explosão de um tiro de canhão", nas palavras de Kirkpatrick ([1953] 1983, p. 297) - que invade o movimento contínuo de semicolcheias e requer saltos gigantescos das duas mãos em direções opostas. Esse gesto soa tremendamente conclusivo, mas nenhuma progressão cadencial sequer foi iniciada. Como se para compensar esta ausência, uma ideia cadencial de última hora se inicia, porém a música "retorna" imediatamente ao compasso 29, sugerindo de forma enfática a estratégia "mais uma vez". Após o segundo tiro de canhão, a progressão cadencial se recupera a tempo de articular uma cadência autêntica com elisão no compasso 34.

Como na primeira parte, a seção de fechamento baila ao som de uma sequência por terças descendentes; ela parece fugir de sua cadência no compasso 36 , repete seu padrão uma segunda vez e conclui com uma cadência no compasso 38. Podemos observar aqui que, no decorrer dessa temerária segunda metade, Scarlatti emprega habilmente quatro das seis categorias possíveis de sequência harmônica: grau conjunto ascendente, grau conjunto descendente, quintas descendentes e terças descendentes. Exemplos das duas categorias restantes, dentre outras,-aquelas menos comuns, por terças ascendentes e por quintas ascendentes-podem ser encontradas, respectivamente, em sua Sonata K. 394 (transição, c. 16-24) e em sua descontroladamente errante K. 426 (c. 15-25, na qual a progressão Lá,-Mib-Sib, no entanto, não é reforçada por um plano melódicocontrapontístico de modelo e sequência). Progressões sequenciais, um elemento importante da música Barroca e de épocas seguintes, correm soltas no "estilo misto" de Scarlatti; as ocorrências de representantes notavelmente diversos das seis classes de sequências em suas sonatas demandam uma pesquisa mais aprofundada. ${ }^{44}$

${ }^{44}$ Sutcliffe dedica uma seção inteira de seu capítulo intitulado "Sintaxe" ao "sinal sintático médio mais característico - a sequência" (2003, p. 181); ele identifica as sequências de acordo com seus padrões intervalares lineares, ao invés de utilizar as seis categorias de Caplin ou a terminologia do partimento, mas ele certamente conhece toda a gama de tipos sequenciais que Scarlatti explora. Por outro lado, Sutcliffe argumenta que Scarlatti "simplesmente evita a típica dicção da sequência barroca", uma forma de padronização que, "previsível e unitária", permanece "relativamente sem transformações ao final do século" (p. 182). Por outro lado, Scarlatti pode "perverter a sequência barroca" por meio de "cruzamentos de mãos" virtuosísticos (p. 182; vide K. 27, discutido acima); pode romper suas proporções, tornando-as "uma clara reductio ad absurdum" (p. 184, como na K. 293); pode prejudicar sua "dicção interna", como na K. 427, 


\section{Um retorno para a (e no interior da) K. 159}

Retorno agora à segunda parte da Sonata em Dó maior, K. 159 (Ex. 10), e ao amplo tópico com o qual comecei: a questão da forma como um todo. Das cinco sonatas que exploramos, apenas uma delas, o Andante em Fá menor, K. 481, rompeu com as convenções da sonata Tipo 2 e o seu plano de rotação dupla. Por mais que quiséssemos afirmar que essa sonata antecipa um tipo formal "posterior", nossos esforços não foram bem-sucedidos. No entanto, dentre todas as 555 sonatas de Scarlatti sobreviventes, há um movimento-apenas um-cuja estrutura formal incentiva um debate sério. A Sonata em Dó maior pode atender aos amplos requisitos da forma sonata Clássica de Tipo 3? Nesta última empreitada, vamos considerar esta possibilidade.
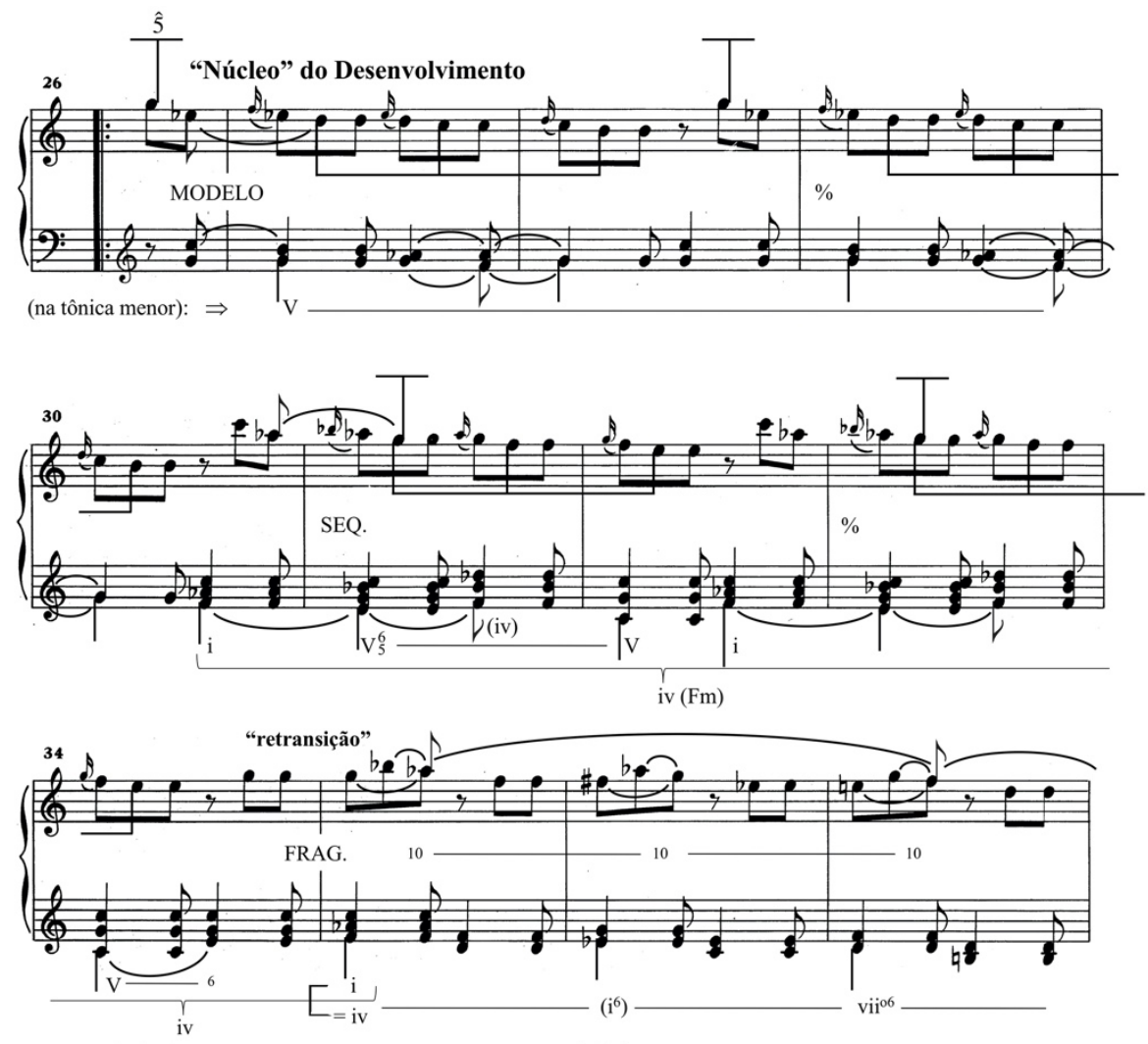

compassos 26-29 (vide Ex. 9b novamente), onde ele apresenta "dois membros completos e o início de um terceiro antes do padrão ser engolido, por assim dizer, pela onda de animação característica da tocata" (p. 184). Em resumo, um tipo de Verfremdung-um distanciamento, ou "estranhamento", ou talvez até um "desprezo" pela convenção (p. 182)-caracteriza, para Sutcliffe, o tratamento de Scarlatti de sequências harmônicas (vide sua discussão sobre o conceito de Verfremdung, p. 179). 
MUSICA THEORICA Revista da Associação Brasileira de Teoria e Análise Musical 2020, v. 5, n. 1, p. 1-52 - Journal of the Brazilian Society for Music Theory and Analysis @ TeMA 2020 - ISSN 2525-5541
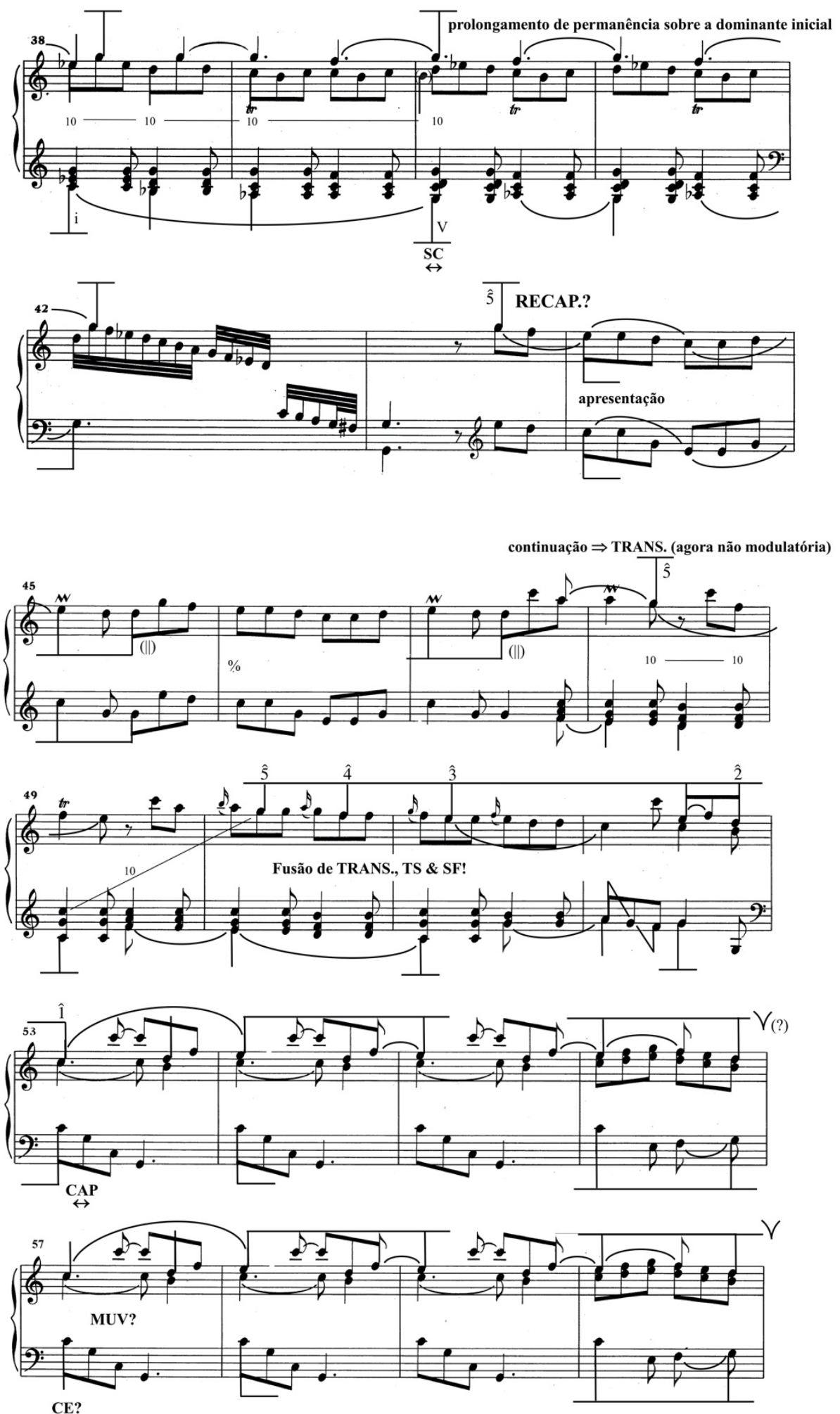

CE? 


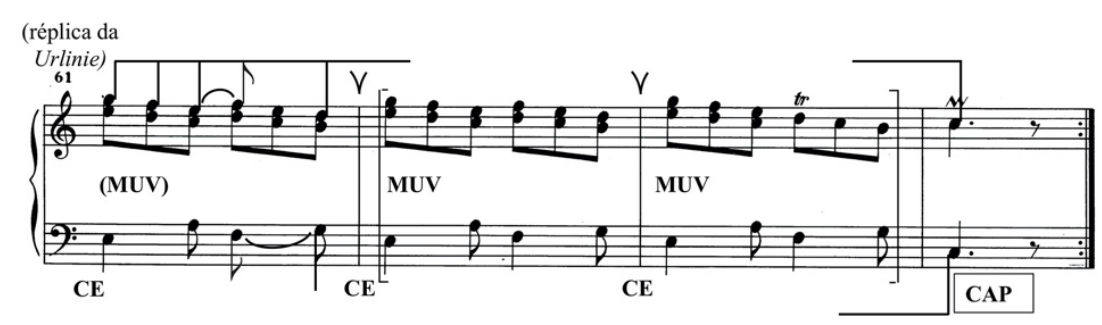

Exemplo 10: Scarlatti, Sonata em Dó maior, K. 159, c. 26-64

Propus que a breve primeira parte desta sonata (vide novamente o Ex. 6) apresenta uma clara abertura orientada à tônica, uma transição para a dominante e, em seguida, um tema duplo secundário/final-todas as três funções formais essenciais que esperamos não apenas nas exposições de Scarlatti, mas também em uma exposição Clássica, embora, devemos admitir, aqui apresentadas em uma forma extremamente comprimida. A segunda parte-e não "metade", pois esta é duas vezes mais longa que a primeira-se inicia convertendo a tonalidade da dominante, Sol maior, no acorde de dominante da tônica menor. Neste ponto, abre-se um "espaço de desenvolvimento" e uma segunda rotação parece começar, tudo isso no modo da tônica menor. Sobre o pedal de dominante, a ideia inicial e sua repetição se referem à continuação da primeira parte da seção de abertura (c. 7-8). Uma sequência sobre a subdominante (iv) dá lugar a um processo de fragmentação (c. 35-40) cujo papel será recuperar a dominante da tonalidade inicial; aqui, a fragmentação é coordenada com uma sequência descendente por graus conjuntos que começa a acelerar no compasso 38. Agora a exuberância "espanhola" da sonata vem à tona: com o dobramento da suspensão 7-6 criando um choque cruel, o baixo continua seu movimento descendente através do tetracorde frígio em direção à semi-cadência do compasso 40; um acorde de acciaccatura nunca resolvido (o termo significa "compressão") - uma das marcas registradas mais famosas de Scarlatti-anuncia brutalmente a chegada da dominante. Um deslumbrante floreio, ao estilo de uma cadenza, traz esta seção ao fim com uma vistosa arrogância.

Nada, nesta passagem, se afasta das segundas metades características do compositor até o momento em que precisamos reconhecer que a chegada e permanência sobre a dominante da tonalidade inicial dramatizam o desfecho de forma enfática, marcado até mesmo por um silêncio curto, mas palpável-a mais breve das cesuras - no compasso 43. Retrospectivamente, podemos observar que 
a passagem como um todo começou precisamente com o que Caplin denomina "núcleo" do desenvolvimento - isto é, com modelo, sequência e fragmentação. ${ }^{45}$ A passagem contendo fragmentação invoca o caráter de uma retransição, embora uma modulação autêntica não seja necessária. Somado a estas características, o final vigoroso sobre a dominante parece implorar para que a passagem completa seja percebida como um desenvolvimento em miniatura, no sentido tardio deste termo. A partir desta perspectiva, é difícil imaginar o que poderia então ter seguido, além de uma genuína recapitulação Clássica. Dito e feito, os materiais de abertura da sonata retornam agora na tonalidade inicial. Em outras palavras, há aqui um "retorno duplo" - das chamadas de trompa do início da sonata e da retomada vitoriosa da tônica no modo maior.

Agora, uma terceira rotação se inicia. O retorno da frase de apresentação que abre a sonata conduz à sua "continuação", aqui transposta para permanecer na tonalidade inicial (nos c. 48-53); em seguida, vemos o retorno do tema secundário/de fechamento completo na tonalidade inicial, juntamente com os arremates "mais uma vez", exatamente como esperaríamos de formas de sonata posteriores a esta. O que, então, contraria a ideia de que uma "forma sonata Clássica" bastante compacta acaba de ser concluída?

Sheveloff, descrevendo as formas de sonata de Scarlatti de maneira geral, enfatiza que "não há a recapitulação da abertura do movimento na tônica durante a segunda parte e, portanto, não há um allegro de sonata (salvo na K. 159, e isso parece ter sido o resultado de um acidente do desenvolvimento motívico)" (1980, p. 572; grifo meu). Ralph Kirkpatrick, em 1953, vai ainda mais longe: “. . . a inventividade de Scarlatti é tal que ele seria perfeitamente capaz de descobrir a forma sonata Clássica e depois jogá-la fora" ([1953] 1983, p. 266). Curiosamente, Sutcliffe omite completamente uma discussão sobre a K. 159. Como Kirkpatrick certamente sabia, teria sido difícil para Scarlatti, presumivelmente isolado na corte de Maria Bárbara em Madri, ter "descoberto" a forma sonata Clássica de Tipo 3, exceto em sua própria imaginação, ou-como um tiro no escuro ainda sem fundamento-por meio de tendências emergentes do Tipo 3 presentes na música importada para a Espanha que ele possa ter ouvido. O que deve ser reconhecido, penso eu, é que, através da experimentação e de pura genialidade, este compositor chegou a uma forma, embora apenas uma vez, que se tornou

\footnotetext{
${ }^{45}$ Caplin (1998, p. 142-147); vide também Caplin (2013, p. 273-274, 422 e 429-430).
} 
dominante no final do século XVIII. Sua conquista, mesmo que apenas "acidental", deve ser considerada notável.

Mas Scarlatti, meu artista fugidio, fugiu deste tipo de reconhecimento. Certamente, os grandes especialistas em Scarlatti e os amantes de sua música concederam-no o status de gênio com respeito a muitas dimensões musicais, incluindo a harmonia. Aqui está Kirkpatrick novamente: "Fosse a música de Domenico Scarlatti inteiramente explicável em palavras, não valeria a pena explicá-la. Minha intenção é apenas mostrar em seu contexto as características mais salientes da harmonia de Domenico Scarlatti, e não aprisioná-las em um sistema do qual elas escapariam imediatamente" ([1953] 1983, p. 208). Com poucas exceções, os analistas também permitiram que o "estilo misto" do compositor, de maneira geral, escapasse de seu lugar na música da metade do século XVIII e de seu papel como prenúncio de técnicas composicionais posteriores. Este artigo deve ser compreendido apenas como uma tentativa [um esforço] de se colocar a música de Scarlatti em contato com teorias recentes sobre formas Clássicas, tipos temáticos, sequências, estruturas fraseológicas e estratégias cadenciais. Há muito mais que ainda aguarda nossa consideração. Por exemplo, questões sobre em que medida as técnicas schenkerianas e os estudos sobre esquemas galantes, partimento e tópicas do século XVIII têm relevância para sua música permanecem pouco estudadas. ${ }^{46}$ Mas podemos estar seguros de

\footnotetext{
${ }^{46}$ Sutcliffe fez incursões intensas sobre as questões dos esquemas galantes e da teoria das tópicas com relação à música de Scarlatti. Em sua resenha (2009) de Gjerdingen (2007), Sutcliffe responde à alegação de Gjerdingen de que Mozart "é um caso especial por sempre posicionar suas declarações às margens do que seria um comportamento musical aceitável" (Gjerdingen 2007, p. 436). Sutcliffe diz: "Questiona-se as alegações de um Domenico Scarlatti mencionado várias vezes anteriormente com a implicação de ser um membro de carteirinha do clã galante da corte, ou mesmo de um Haydn" (2009, p. 472). Sutcliffe (2014) descreve as sonatas para teclado de Scarlatti como "talvez o primeiro repertório topicamente volátil": "É instrutivo que escritores tenham tentado identificar tópicas nas sonatas de Scarlatti há bastante tempo, muito antes do advento da teoria das tópicas e de sua aplicação em um território que abrigou o classicismo vienense" (p. 122); e "embora muitas das sonatas de Scarlatti possam ser acomodadas mais ou menos dentro da compreensão prevalecente do jogo tópico, como encontrado no final do século XVIII [ . . .] há outras características que colocam em dúvida não apenas o princípio da mutabilidade, mas a noção de tópica como fundamental para este processo. Por exemplo, muitas das sonatas promovem [. . .] uma mudança gradual de estilo ou tópica sem que existam pontos de descontinuidade demarcados no tratamento do material" (p. 122-123). Sutcliffe pergunta se o que ele mesmo rotula como "exótico" na K. 181 de Scarlatti pode ser considerado uma "tópica": "[M]as como isso pode ser possível quando pouquíssimos ouvintes da época poderiam ter percebido este material, não teriam, portanto, a experiência de um momento de reconhecimento,
} 
MUSICA THEORICA Revista da Associação Brasileira de Teoria e Análise Musical 2020, v. 5, n. 1, p. 1-52 - Journal of the Brazilian Society for Music Theory and Analysis @ TeMA 2020 - ISSN 2525-5541

que nenhuma dessas abordagens atualizadas de suas obras diminuirá o que já é certo: que ele permanecerá para sempre como um dos artistas mais espetaculares e fugidios do teclado no século XVIII e além.

\section{Referências}

1. Berry, David Carson. 2012. Review of Advanced Schenkerian Analysis: Perspectives on Phrase Rhythm, Motive, and Form by David Beach. Intégral, 26, p. 159-197.

2. Boyd, Malcolm. 1985. Nova Scarlattiana. The Musical Times, 126/1712, p. 589593.

3. 1987. Domenico Scarlatti: Master of Music. New York: Schirmer Books.

4. Caplin, William E. 1998. Classical Form: A Theory of Formal Functions for the Instrumental Music of Haydn, Mozart, and Beethoven. New York: Oxford University Press.

5 . . 2010. Beethoven's "Tempest" Sonata: A Response to Janet Schmalfeldt. Music Theory Online, 16/ii.

6. 2013. Analyzing Classical Form: An Approach for the Classroom. New York: Oxford University Press.

7. Caplin, William E., and Nathan John Martin. 2016. The "Continuous Exposition" and the Concept of Subordinate Theme. Music Analysis, 35/1, p. 4-43.

8. Clark, Jane. 1976. Domenico Scarlatti and Spanish Folk Music: A Performer's Re-appraisal. Early Music, 4/i, p. 19-21.

9. 2000. Notes to Domenico Scarlatti: an Italian in Spain, harpsichord recording by Jane Clark, Janiculum, D204.

10. d'Alvarenga, João Pedro. 2008. Domenico Scarlatti in the 1720s: Portugal, Travelling and the Italianization of the Portuguese Musical Scene. In: Massimiliano Sala and W. Dean Sutcliffe (eds), Domenico Scarlatti Adventures: Essays to Commemorate the 250 th Anniversary of His Death (Bologna: Ut Orpheus Edizioni), p. 17-68.

em outras palavras, não seriam ouvintes 'competentes'? Se esta é uma tópica, a definição deve ser concebida a partir de uma perspectiva mais ampla" (p. 129). 
11. Doderer, Gerhard. 1991. New Aspects Concerning the Stay of Domenico Scarlatti at the Court of King John V (1719-1727). Prefácio ao facsimile, Libro di tocate per cembalo: Domenico Scarlatti (Lisboa: Instituto Nacional de Investigação Científica), p. 9-10.

12. Fadini, Emilia. 2008. Domenico Scarlatti: integrazione tra lo stile andaluso e lo stile italiano. In: Massimiliano Sala and W. Dean Sutcliffe (eds), Domenico Scarlatti Adventures: Essays to Commemorate the 250th Anniversary of His Death (Bologna: Ut Orpheus Edizioni), p. 155-196.

13. Gilbert, Kenneth (ed). 1971-1984. Domenico Scarlatti: Sonates, vols. 1-11 (Paris: Heugel).

14. Gjerdingen, Robert O. 2007. Music in the Galant Style. Oxford e New York: Oxford University Press.

15. Green, Douglass M. 1979. Form in Tonal Music: An Introduction to Analysis, 2a ed.. New York: Holt Rinehart and Winston.

16. Hepokoski, James, and Warren Darcy. 2006. Elements of Sonata Theory: Norms, Types, and Deformations in the Late-Eighteenth-Century Sonata. New York: Oxford University Press.

17. Hepokoski, James. 2009. Approaching the First Movement of Beethoven's Tempest Sonata through Sonata Theory. In: Pieter Bergé (ed), Jeroen D'hoe and William E. Caplin (co-eds), Beethoven's "Tempest" Sonata: Perspectives of Analysis and Performance (Leuven: Peeters).

18. Kirkpatrick, Ralph. 1953. Domenico Scarlatti. Princeton: Princeton University Press.

19. Kroll, Mark. 2004. Review of The Keyboard Sonatas of Domenico Scarlatti and Eighteenth-Century Musical Style, by W. Dean Sutcliffe. Notes (2nd series), 61/i, p. 145-147.

20. Moiraghi, Marco. 2014. Forma e funzioni formali. In: Enrico Baiano and Marco Moiraghi (eds), Le Sonate di Domenico Scarlatti: Contesto, Testo, Interpretazione (Libreria Musicale Italiana), p. 148-178.

21. Perahia, Murray. 1997. Murray Perahia Plays Handel and Scarlatti, DDD SK 62785, Sony.

22. Pestelli, Giorgio. 1967. Le sonate di Domenico Scarlatti: proposta di un ordinamento cronologico. Turin: Giappichelli.

23. 1985. The Music of Domenico Scarlatti. In: Domenico Scarlatti: Grosse Jubiläen im Europäischen Jahr der Musik (Kulturzentrum Beato Pietro Berno 
MUSICA THEORICA Revista da Associação Brasileira de Teoria e Análise Musical 2020, v. 5, n. 1, p. 1-52 - Journal of the Brazilian Society for Music Theory and Analysis@ TeMA 2020 - ISSN 2525-5541

Ascona: Ausstellung 24 August-30 October 1985), 2a ed (Locarno: Pedrazzini Editions), p. 79-92.

24. Puyana, Rafael. 1988. Notes on Scarlatti: Trente Sonates, recording on a threemanual harpsichord, Harmonia Mundi. s. a., Mas de Vert, 13200, Arles.

25. Ross, Scott. 1984-85. Domenico Scarlatti, The Complete Keyboard Sonatas. Erato, 0825646299454.

26. Sanguinetti, Giorgio. 2012. The Art of Partimento: History, Theory, and Practice. Oxford e New York: Oxford University Press.

27. Schenker, Heinrich. 1994. Domenico Scarlatti: Keyboard Sonata in D minor; e Domenico Scarlatti: Keyboard Sonata in G Major, trans. Ian Bent. In: William Drabkin (ed), The Masterwork in Music, vol. 1 [1925] (Cambridge: Cambridge University Press), p. 67-74, p. 75-80.

28. Schmalfeldt, Janet. 1992. Cadential Processes: The Evaded Cadence and the "One More Time" Technique. Journal of Musicological Research 12/i-ii, p. 1-52.

29. .2011. In the Process of Becoming: Analytic and Philosophical Perspectives on Form in Early Nineteenth-Century Music. New York: Oxford University Press.

30. Sheveloff, Joel. 1970. The Keyboard Music of Domenico Scarlatti: a Reevaluation of the Present State of Knowledge in the Light of the Sources. PhD diss., Brandeis University.

31. 1980. (Giuseppe) Domenico Scarlatti. In: Stanley Sadie with Nigel Fortune (eds), New Grove Dictionary of Music and Musicians, vol. 16 (Oxford: Oxford University Press), p. 568-578.

32. Sutcliffe, W. Dean. 2001. Binary Form. In: The New Grove Dictionary of Music and Musicians, 2a ed., Stanley Sadie and John Tyrrell (eds), vol. 3 (London: Macmillan), p. 576-578.

33. 2003. The Keyboard Sonatas of Domenico Scarlatti and EighteenthCentury Musical Style. Cambridge: Cambridge University Press.

34. .2009. Review of Music in the Galant Style, by Robert O. Gjerdingen (New York: Oxford University Press, 2007). Music and Letters, 90/iii, p. 468473.

35. 2014. Topics in Chamber Music. In: Danuta Mirka (ed), The Oxford Handbook of Topic Theory (New York: Oxford University Press), p. 118-140.

36. Talbot, Michael. 1990. Modal Shifts in the Sonatas of Domenico Scarlatti. In: Domenico Scarlatti e il suo tempo (Chigiana 40), Anais, Siena, 2-4 de setembro 
de 1985, organizada pela Accademia Musicale Chigiana Musicologia e pela Università degli Studi juntamente com a Società Italiana di Napoli (Florença: Olschki).

37. Wingfield, Paul. 2008. Beyond "Norms and Deformations": Towards a Theory of Sonata Form as Reception History. Music Analysis, 27/i, p. 13-40.

38. Zbikowski, Lawrence M. 2010. Music, Emotion, Analysis. Music Analysis, 29/i-iii, p. 37-60. 